NBER WORKING PAPER SERIES

\title{
THE EFFECTS OF RECONSTRUCTION FINANCE CORPORATION ASSISTANCE ON MICHIGAN'S BANKS' SURVIVAL IN THE 1930S
}

\author{
Charles W. Calomiris \\ Joseph R. Mason \\ Marc Weidenmier \\ Katherine Bobroff \\ Working Paper 18427 \\ http://www.nber.org/papers/w18427 \\ NATIONAL BUREAU OF ECONOMIC RESEARCH \\ 1050 Massachusetts Avenue \\ Cambridge, MA 02138 \\ September 2012
}

This paper was prepared for the National Bureau of Economic Research Conference, "The Microeconomics of New Deal Policy," July 26-27, 2012. For helpful comments, we thank Price Fishback, Eugene White, Kris Mitchener, Larry Neal, Gary Richardson, Eric Hilt, Shawn Kantor, and other participants in the February 2012 "pre-conference," and July 2012 conference for helpful comments on an earlier draft. Adonis Antoniades and Guojun Chen provided superb research assistance. The views expressed herein are those of the authors and do not necessarily reflect the views of the National Bureau of Economic Research.

NBER working papers are circulated for discussion and comment purposes. They have not been peerreviewed or been subject to the review by the NBER Board of Directors that accompanies official NBER publications.

(C) 2012 by Charles W. Calomiris, Joseph R. Mason, Marc Weidenmier, and Katherine Bobroff. All rights reserved. Short sections of text, not to exceed two paragraphs, may be quoted without explicit permission provided that full credit, including $\odot$ notice, is given to the source. 
The Effects of Reconstruction Finance Corporation Assistance on Michigan's Banks' Survival in the 1930s

Charles W. Calomiris, Joseph R. Mason, Marc Weidenmier, and Katherine Bobroff

NBER Working Paper No. 18427

September 2012

JEL No. G01,G18,G21,G28,N12,N22

\section{$\underline{\text { ABSTRACT }}$}

This paper examines the effects of the Reconstruction Finance Corporation's (RFC) loan and preferred stock programs on bank failure rates in Michigan during the period 1932-1934, which includes the important Michigan banking crisis of early 1933 and its aftermath. Using a new database on Michigan banks, we employ probit and survival duration analysis to examine the effectiveness of the RFC's loan program (the policy tool employed before March 1933) and the RFC's preferred stock purchases (the policy tool employed after March 1933) on bank failure rates.

Our estimates treat the receipt of RFC assistance as an endogenous variable. We are able to identify apparently valid and powerful instruments (predictors of RFC assistance that are not directly related to failure risk) for analyzing the effects of RFC assistance on bank survival. We find that the loan program had no statistically significant effect on the failure rates of banks during the crisis; point estimates are sometimes positive, sometimes negative, and never estimated precisely. This finding is consistent with the view that the effectiveness of debt assistance was undermined by some combination of increasing the indebtedness of financial institutions and subordinating bank depositors. We find that RFC's purchases of preferred stock - which did not increase indebtedness or subordinate depositors - increased the chances that a bank would survive the financial crisis.

We also perform a parallel analysis of the effects of RFC preferred stock assistance on the loan supply of surviving banks. We find that RFC assistance not only contributed to loan supply by reducing failure risk; conditional on bank survival, RFC assistance is associated with significantly higher lending by recipient banks from 1931 to 1935.

Charles W. Calomiris

Graduate School of Business

Columbia University

3022 Broadway Street, Uris Hall

New York, NY 10027

and NBER

cc374@columbia.edu

Joseph R. Mason

Patrick F. Taylor 2164-A

E. J. Ourso College of Business

Louisiana State University

Baton Rouge, LA 70803

joseph.r.mason@gmail.com
Marc Weidenmier

Robert Day School of Economics and Finance

Claremont McKenna College

500 East Ninth Street

Claremont, CA 91711

and NBER

marc_weidenmier@claremontmckenna.edu

Katherine Bobroff

Harvard Business School

Soldiers Field

Boston, Massachusetts 02163

klbobroff@gmail.com 


\section{Introduction: RFC Assistance to Banks During the Depression}

This paper examines the effects of the Reconstruction Finance Corporation's (RFC) loan and preferred stock programs on bank failure rates of Michigan banks during the period 1932-1934, which includes the important Michigan banking crisis of early 1933. Using a new database collected from primary sources, we employ probit and survival duration models to examine the effectiveness of the government's loan program and preferred stock purchases on bank survival and failure rates, and on loan growth of surviving banks. We study Michigan banks because the failure to stem Michigan's statewide banking crisis has been viewed by some historians of the Depression as a critical precipitator of the national financial crisis of 1933 (Kennedy 1973). The prevalence of bank failures in Michigan during the period 1932-1934 provides a rich data set to examine the determinants of failure, and the potential salutary effects of government assistance.

The Reconstruction Finance Corporation (RFC) was a government-sponsored enterprise founded to stem bank failures and reduce the economic costs of financial disintermediation. The RFC was originally established to lend funds to troubled firms. However, beginning in March 1933, the Corporation shifted from lending to banks to directly recapitalized banks by purchasing their preferred stock. The program disbursed approximately $\$ 200$ billion in current U.S. dollars (Lohr 2008). When the RFC ceased operations in the early 1950s, the government-sponsored entity sold its preferred stock and recovered the funds provided by taxpayers. 
Herbert Hoover established the RFC on February 2, 1932. ${ }^{1}$ The RFC was originally established to stimulate the economy by increasing liquidity in the financial system by loaning funds to troubled financial institutions. The RFC was an agency of the executive branch of the federal government that had the ability to increase its lending capacity and oversight powers by executive order. Its operations did not depend on Congressional approval (Mason 2003).

During the Great Depression, the RFC conducted four major aid programs: a loan program for financial institutions, a preferred stock program for financial institutions, a railroad loan program, and a commercial and industrial loan program. ${ }^{2}$ The loan program for financial institutions was the first program initiated by the RFC, and it was largely replaced by a preferred stock program; there were few RFC loans made to banks after March 1933, with the exception of loans made to assist the liquidation of failed banks.

While the RFC's charter permitted the Corporation to make loans with maturities of up to three years, most loans had maturities of less than six months. The threat of nonrenewal was perceived as giving the RFC necessary influence over bank management practices. The RFC also demanded high-quality and liquid collateral for its loans, charged an interest rate higher than the rates charged on Federal Reserve loans, and required recipient banks to limit the salary of employees for the life of the loan.

\footnotetext{
${ }^{1}$ This history of the Reconstruction Finance Corporation is based on Mason (2001b).

2 The RFC's railroad loan program, like its bank loan program, was part of the original RFC Act. However, unlike its loans to banks, the RFC's railroad loans did not need to be fully secured. The RFC also lent to railroads at below market rates. As a result of these lax lending polices, the RFC's railroad loan program was abused, and funds were used for the benefit of railroad company insiders (Mason 2001b).

The commercial and industrial loan program was the final economic stimulation program undertaken by the RFC during the Great Depression. Because the banks had ceased lending, the RFC made loans directly to businesses. The RFC encouraged banks to purchase the right to participate in commercial and industrial loans instead of originating the loans themselves in order to stimulate private sector lending. However, during the Great Depression, consumers were not increasing their demand for goods or services. As a result, no businesses needed to invest in additional capacity. The commercial and industrial loan program therefore had little impact on the economy.
} 
The short duration, strict collateralization rules, and high interest of RFC loans may have protected the RFC from loss, but it also may have limited the effectiveness of RFC lending. Banks that received such assistance became more indebted as a consequence of it, and were not given much additional time to restore market confidence in their solvency. Because the RFC demanded high-quality collateral, the RFC's loans also effectively stripped banks of their best assets, thereby effectively subordinating depositors - who retained general claims on the remaining assets of the bank, an asset pool of lower quality than RFC collateral. Increased leverage, short maturity, and the subordination of depositors increased the riskiness of recipient banks' deposits, and may have encouraged depositor runs, as many critics of the RFC lending program contended (Olson 1977, Mason 2001a). The strict terms of RFC lending and the control the RFC exercised over bank management also allegedly discouraged financial institutions from using the RFC's loan program. According to Olson (1972), the RFC's loan conditions were generally perceived as bringing “more problems than solutions.” In Olson's (1972, p. 177) view, RFC loans "helped only those basically sound enterprises that needed temporary liquidity." James (1938) corroborates this view: "High collateral requirements forced [banks] to isolate their most liquid assets as security for RFC loans. In April 1932, for example, the Reconstruction Finance Corporation loaned the Reno National Bank over $\$ 1,100,000$, but in the process took as collateral over $\$ 3,000,000$ of the bank's best securities. This in itself left the bank unable to meet any future emergency demands for funds by depositors." The only econometric analysis of the loan program's effectiveness, based on the failure experience of banks in the Chicago Federal 
Reserve District, suggests that the decision to borrow from the RFC did not prevent bank failures, and may have contributed to the risk of failure (Mason 2001a).

To correct the perceived flaws of the loan program, the RFC moved from a policy designed primarily to increase short-term liquidity to one that reduced the default risk of deposits by increasing the capital of assisted banks. On March 9, 1933, Congress passed the Emergency Banking Relief Act, altering the original mandate of the RFC to permit the government-sponsored entity to purchase preferred stock in financial institutions. ${ }^{3}$ RFC assistance was not available to all banks; only to those that were deemed sufficiently likely to survive as the result of receiving the assistance. Statistical analysis by Mason (2001a) of Chicago Fed District recipients indicates that the banks that issued preferred stock to the RFC were of middling risk compared to other banks at the time they received assistance.

RFC preferred stock was junior to deposits and other debts, but senior to common stock upon liquidation of a bank. After the issuance of the RFC's preferred stock, common stock dividends were strictly limited, and the RFC undertook additional measures to ensure that banks accumulated additional capital and did not abuse government protection (Upham and Lamke 1934, Cho 1953). RFC preferred stock carried voting rights that gave it the power to institute changes that would increase the solvency and profitability of a bank. The bank's earnings were placed in a retirement fund that would be used to buy back the RFC's preferred stock.

The RFC's rules and control rights over financial institutions that participated in the preferred stock program seem to have discouraged some banks from participating. Furthermore, banks also expressed concern that participating in the aid program would

\footnotetext{
${ }^{3}$ Emergency Banking Relief Act, Section 304. $73^{\text {rd }}$ Congress, 1933.
} 
make them seem weak, causing depositors and shareholders to lose confidence and withdraw their funds from banks. As a result, widespread participation in the preferred stock program occurred only when the FDIC began backing some of the deposits in solvent banks in 1934. For large banks, FDIC insurance limits meant that only a small proportion of their deposits were insured, but for small banks in rural areas, FDIC coverage insured a much larger proportion of deposits.

Insurance coverage was offered only after many insolvent banks were closed in 1933, leaving the remaining banks to be insured by the FDIC and assisted by the RFC. ${ }^{4}$ Deeply insolvent banks were closed; marginal banks were assisted and insured, and clearly solvent banks were insured without assistance.

Managers of relatively strong and weak banks alike sold preferred stock to the RFC, purportedly to protect the identities of the institutions that were too weak to join the FDIC without additional investment. As a result, the RFC eventually owned more than one-third of the capital of American banks (Mason 2001b). Econometric analysis of Chicago Fed District banks suggests that recapitalizing the banks with preferred stock helped to stabilize the banking sector, although the program did not increase lending by those banks (Mason 2001a).

The ambitious programs and immense resources of the RFC subjected the agency to political pressure and public scrutiny. State and federal politicians, recognizing the benefits of RFC aid, often pressured the government-sponsored enterprise to grant

\footnotetext{
${ }^{4}$ According to Jesse Jones, the chairman of the RFC, more than 5,000 banks which had previously claimed to be solvent "required considerable added capital to make them [sufficiently] sound" to join the FDIC (Jones and Pforzheimer, 1951, p. 27). Jones personally appealed to the managers of all banks to join the RFC's stock program "so that depositors would not be induced to switch out of ...banks when their names were published" (p. 26-27). Thanks to the preferred stock program, the weaker banks were adequately recapitalized and all but 141 of approximately 14,500 American banks joined the FDIC in 1934 (Federal Deposit Insurance Corporation).
} 
assistance to their constituents. Concerns about RFC accountability ultimately led Congress to require the publication of the names of its aid beneficiaries.

Econometric analysis of the identities and characteristics of the recipients of aid distributed by the RFC have not been able to identify evidence that the Corporation was not swayed by political influence in its lending policies, where political influence is defined as systematic biases related to political partisanship, Congressional committees and the like (Mason 2003). ${ }^{5}$ The potential for the manipulation of the RFC by Congress or the Administration was mitigated by three main factors. First, the loans made by the RFC to financial institutions had to be fully and adequately secured. ${ }^{6}$ This restriction was also incorporated into the RFC's credit and capital programs, which ensured that aid recipients were good candidates for recovery. Second, the RFC was funded as a government-owned corporation with an initial appropriation from Congress and capital subsidies from the Treasury. The managers of the RFC relied upon this capital base rather than regular Congressional appropriations, which freed the RFC's managers from having to concern themselves about ongoing political pressure from Congress. Finally, RFC aid decisions were made at the regional level; each region's field office was largely independent from the others and appears to have been largely immune to political influences from Washington. Field offices were given a large degree of autonomy over assistance decisions, but also were held accountable to the central office if their decisions adversely affected RFC earnings (Delaney 1954).

\footnotetext{
${ }^{5}$ This study does not test for the personal influence of particular bankers on the allocation of RFC funding. Not surprisingly, given the extent of RFC lending, some of the banks that received RFC assistance were associated with politically influential individuals, who were also connected to the RFC, including Jesse Jones and Charles Dawes. Whether the likelihood of assistance was affected by such personal connections remains unexplored empirically. Doing so would require the mapping of the personal and business connections of bank officers and board members, which is beyond the scope of this paper.

${ }^{6}$ The RFC did not specify the level of collateral that was necessary and only its staff could evaluate whether a bank had sufficient assets to secure a loan (Mason 2001b).
} 
Mason (2001a) and Calomiris and Mason (2004) conduct in-depth analyses of the operations of the RFC in the Chicago Federal Reserve District, distinguishing between the effects of RFC loans and preferred stock purchases on Chicago Federal Reserve member banks. The analysis suggests that as the RFC assumed greater default risk, its aid programs more successfully limited bank failures. RFC loans did not lower bank failure rates. RFC loans, like Fed discounting, was designed to deal with illiquidity problems, not shocks that threatened bank solvency. In contrast, the preferred stock program helped prevent banks from failing because they channeled resources to banks (subsidized injections of capital) that reduced insolvency risk. Mason suggests that marginally solvent banks receiving preferred stock assistance could operate more efficiently and regain strength as a result of government infusions of capital stock.

While these findings are important and suggestive, it is not clear whether they apply to other regions of the country, which suffered different histories of bank distress during the Great Depression. Chicago's deepest moment of crisis was its panic of June 1932, long before the nationwide panic that gripped the banking system in March of 1933 (Calomiris and Mason 1997, 2003a). In this study, we examine whether similar consequences of RFC assistance can be discerned for Michigan banks. The timing and extent of Michigan banking distress perhaps most closely tracked the sudden and widespread panic that gripped the U.S. in early 1933, and therefore, provides an important further test of the effectiveness of RFC preferred stock assistance in reducing the costs of banking distress in 1933 and its aftermath. 


\section{Michigan Banks and the Nationwide Panic of 1933}

The Great Depression saw the worst waves of banking distress that had gripped the country since the late 1830s. Calomiris and Mason (2003a) review the history, and causal influences, relating to the waves of failures that occurred from 1930 to 1933 . From November 1932 to February 1933, banking distress accelerated, and systemwide banking crises gripped Nevada, Wisconsin, Pennsylvania, Minnesota, Tennessee, Ohio, Arkansas, Alabama, Missouri, Maryland, Louisiana, and Michigan. Calomiris and Mason (2003a) show that the nationwide panic of early 1933 differed from prior waves of bank failure; ${ }^{7}$ unlike prior episodes of distress, the probability of failure rose dramatically in early 1933 , not only for banks with weak fundamentals, but for all banks.

The banking crisis in Michigan in February 1933 was of particular importance; indeed, Kennedy (1973) describes the Michigan banking crisis as a "prelude to the national banking disaster three weeks thereafter." The turmoil experienced in Michigan, the home of the American automobile industry, also highlights the devastating effects of banking crises on the national economy.

In Detroit, significant amounts of money began to flow out of the largest banks with the onset of the Great Depression (Awalt 1969). The Detroit Bankers Company Group and the Union Guardian Group, the two major local bank holding companies, were under additional pressure because of their banks' heavy investment in local real estate (New York Times 1933a). ${ }^{8} \quad$ Between 1930 and February 1933, approximately $\$ 250$

\footnotetext{
${ }^{7}$ See Calomiris (2010) on the size of depositor losses during the 1930s. On the policy reaction to the banking distress of the Depression and its aftermath, see Calomiris and White (1994), White (1998) and Calomiris (2010). See Calomiris and Mason (2003b) on the credit supply consequences of banking distress during the Depression.

${ }^{8}$ The Detroit Banks Company Group held the First National Bank of Detroit, Peoples' Wayne County Bank, Detroit Trust Company, eight suburban banks, and a local investment company, the First Detroit Company. The Union Guardian Group, also called the Ford Group, held the National Bank of Commerce,
} 
million was withdrawn from the First National Bank of Detroit; its local competitors, the Union Guardian Trust Company and the Guardian National Bank of Detroit, also sustained massive withdrawals. By January 1933, these banks were losing between $\$ 2.5$ million and \$3 million in deposits each week (Awalt 1969).

These banks not only were large Detroit banks, they were at the center of the largest two banking groups in Michigan. In Michigan, two holding companies - the Guardian Detroit Union Group, and First National People's Wayne Group - controlled 56 banks (35 and 21, respectively), including the First National Bank of Detroit, Union Guardian Trust Company, and Guardian National Bank of Detroit. As of December 1929, the two banking groups accounted for $\$ 1.1$ billion of the $\$ 1.2$ billion in loans and investments that were housed within group and chain banks in Michigan. ${ }^{9}$ In 1929 , Michigan banks affiliated with groups or chains represented 15.9 percent of all Michigan banks, and 54.4 percent of the loans and investments of Michigan banks. ${ }^{10}$ The problems of the Detroit banks, therefore, had broader potential ramifications elsewhere in Michigan. ${ }^{11}$

\footnotetext{
Guardian Union Trust Company, and other local banks (Awalt 1969, 350). First National Bank had book assets of \$485,846,627 and 146 branch offices outside of its main office in Detroit at the time of the crisis; the Guardian Union Group held book assets of \$432,797,434, nine bank components in Detroit and 11 bank branches in other Michigan cities (New York Times 1933b).

${ }^{9}$ Group and chain banks were banks controlled by a centralized governance system, either related to a bank holding company, a main bank, or individual stock holders. US House of Representatives (1930) identifies the number and size of groups and chains in the United States as of December 1929, but it does not list the banks that belonged to chains or groups.

${ }^{10}$ Federal Reserve Board (1943), p. 312.

${ }^{11}$ In our empirical work we considered trying to take account of a bank's position in a group or chain, either as a leader of a group or chain, or as a member of one, to see whether leadership of a chain or membership in one might have affected the probability of receiving RFC assistance, or the probability of failure. The only important group or chain leaders, however, were the banks in Detroit that were reorganized in early 1933, and therefore, are not part of our sample. Furthermore, we could not locate a reliable source for identifying members of groups or chains. Bank encyclopedias (like Polks) do sometimes refer to group and chain connections, but it is not clear whether this is done consistently.
} 
To meet the demands of its depositors, the Guardian Trust Company requested additional funds from the RFC. Henry Ford had already attempted to bolster the bank's liquidity with a $\$ 7$ million deposit. With deposits of approximately $\$ 32.5$ million in the Guardian Banks and an additional \$18 million in the Detroit Bankers' group, Ford had a strong personal incentive to assist the local financial institutions (Awalt 1969). However, Ford's infusion of cash was not enough to sustain the Guardian Trust Company, and the bank requested an additional $\$ 60$ million from the $\mathrm{RFC}$, which was already lending to a number of local banks (New York Times 1933a; New York Times 1933c).

As the RFC considered the application of the Guardian Trust Company, Michigan Senator James Couzens realized that the bank lacked sufficient collateral to justify a standard loan (New York Times 1933a). ${ }^{12}$ Couzens asked Henry Ford to grant the government a lien on his $\$ 7$ million deposit, subordinating his claim to that of the RFC. Ford rejected this plan and an alternative plan that would have required him to sign a personal note for the difference between the bank's collateral and the amount to be loaned by the RFC. Contemporary sources indicate that the Ford family and company had already advanced local banks $\$ 12$ million and considered further efforts to save the banks futile (Awalt 1969). Angered by the increasing pressure from government officials to personally recapitalize the struggling banks, Ford threatened to withdraw \$25 million from the system at the first opportunity. Because it was feared that such a withdrawal would cause a panic and threaten the survival of the local banks, Francis Awalt, acting

\footnotetext{
${ }^{12}$ Couzens and Ford were former business partners in the Ford Motor Company. Couzens was also the chairman of the Senate committee responsible for investigating the RFC's loans, so his concerns about the need for proper collateralization were sufficient cause to block the Union Guardian Trust Company's aid package (New York Times 1933a).
} 
Comptroller of the Currency at the US Treasury, felt compelled to prevent the national banks of Detroit from opening (Awalt 1969).

While Awalt recognized the need to keep all Michigan banks closed, his authority was limited to national banks. Thus, federal officials conferred with Michigan Governor William A. Comstock, who declared a statewide bank holiday on February 14, 1933. The holiday was originally intended to last eight days (Awalt 1969). However, the complex problems plaguing the financial system prompted officials to extend the holiday until March 6 (Awalt 1969).

On February 18, soon after the Michigan bank holiday was declared, news circulated of a potential merger of the Guardian Trust Company and the Central Hanover Bank and Trust Company of New York. Supposedly, "local pride" motivated Detroit bankers to reject the assistance of the New York banks, and local rivalries supposedly prevented the mergers of Detroit banks (New York Times 1933d).

On February 24, Henry Ford and his son Edsel, a Chairman of the Union Guardian Trust Company, offered to provide capital for two new banks to help liquidate the assets of the distressed banks. The aid of the Ford family was offered on the condition that they could select the new bank directors and officers (Awalt 1969). Initially, it seemed that the Ford offer, accompanied by an additional \$20 million from New York bankers and an RFC pledge of $\$ 54$ million, would allow depositors to access at least 35 percent of their deposits immediately (Los Angeles Times 1933). However, the New York bankers withdrew their offer of assistance because of concerns that they might not have clear legal claim to the failing banks' assets. The Ford family then withdrew its contribution, and the bailout plan failed (New York Times 1933e). The failure of the 
bailout plan helped to precipitate a panic across Michigan, which contributed to the panic gripping the rest of the country (Mason 2003, Butkiewicz 1995).

The effects of the financial crisis were felt acutely in the real economy during the weeks between the initial crisis in Detroit and President Roosevelt's inauguration. Detroit was threatened with a milk shortage and grocers were unable to sell food since they could not cash checks (New York Times 1933f; New York Times 1933g). Twentyeight thousand local families supported by the Detroit Public Welfare Department were unable to use their aid checks from the city's accounts with the Guardian Group and First National; Wayne County, Michigan was unable to support 10,000 ill and insane patients because its deposits in the bank groups were unavailable (New York Times 1933g). In late February, the Detroit Clearing House Association considered issuing scrip $^{13}$ to provide a medium of exchange during the banking emergency (New York Times 1933g).

The situation in Michigan and the concurrent exposure of allegedly disreputable business practices among New York bankers exacerbated financial instability across the country. The instability of the Detroit banking system worried officials in Washington, as the public withdrew deposits from banks nationwide. Over 5,500 banks with deposits totaling $\$ 3.4$ billion had temporarily closed by March 3. New York banks lost $\$ 200$ million in gold and $\$ 150$ million in currency; Chicago also lost $\$ 100$ million in gold the same day (Awalt 1969). The Federal Reserve banks admitted "they could not support member banks indefinitely, especially those drained by the troubles in Michigan, Maryland, and Ohio" (Kennedy 1973). However, outgoing President Hoover was unwilling to declare a national bank holiday, so comptroller Awalt and other government officials pressured the governors of several states to declare state banking holidays and

\footnotetext{
${ }^{13}$ Scrip is a certificate of indebtedness issued as currency or in lieu of money (Oxford English Dictionary).
} 
institute banking restrictions. On March 6, the first business day following President Roosevelt's inauguration, he declared a national bank holiday to try to stem the panic.

On March 9, Congress passed the Emergency Banking Relief Act drafted by Roosevelt and his advisors. The Act granted the federal government power over the banking system. ${ }^{14}$ Under this act, the RFC would directly capitalize banks by purchasing preferred stock.

The Emergency Banking Act of 1933 is widely regarded as having helped to resolve the banking crisis. During the national holiday, government officials confirmed the solvency of national banks, which were gradually reopened to their depositors beginning March 13 (although many banks would remain suspended for a much longer time, and some banks never were able to reopen their doors). ${ }^{15}$ Roosevelt's innovative banking plan and first "fireside chat" soothed depositors to such an extent that when banks reopened, deposits actually exceeded withdrawals. Five thousand three hundred eighty-seven of the Federal Reserve's 6,694 member banks reopened by the end of March; 7,654 of 11,455 state institutions also reopened during that time. By June, 91 percent of deposits in Federal Reserve member banks were available to the public. Confidence in the banking system encouraged stock market values to increase; the values of government bonds, corporate bonds and commodities also increased (Kennedy 1973).

After successfully reopening the first set of banks, Roosevelt's administration addressed the long-term capital needs of the banking system. Through investments made

\footnotetext{
${ }^{14}$ The Act also contained provisions for reorganizing national banks and issuing preferred stock for banks. It formalized lending by the Federal Reserve to banks, and created a Presidential discretionary fund of $\$ 2,000,000$ to help carry out the Act.

15 The 1933 Act created the concept of bank "conservatorship," which was a way station between a normal state of affairs and receivership. Many banks that received assistance from the RFC in 1933 were in conservatorship.
} 
by local businessmen and the RFC, the government engineered the direct recapitalization of certain weak banks. The RFC invested more than $\$ 1.2$ billion in over 6,000 institutions during its 18 years of operations. ${ }^{16}$ Ultimately, the agency lost only $\$ 13.7$ million and only 206 of the banks that received RFC preferred stock investments were later forced to close (Kennedy 1973). ${ }^{17}$ The subsidies received by banks (and the implicit taxpayer costs of RFC assistance) should be measured using ex ante costs (the cost savings enjoyed by banks by virtue of their access to government assistance), not the ex post losses. ${ }^{18}$ Nonetheless, the limited losses are indicative of the care with which RFC funds were allocated.

In Detroit, the RFC orchestrated a "Spokane sale" of the assets of the banks. ${ }^{19}$ General Motors and the RFC announced the creation of a new bank on March 21. Half the capital for this new corporation was provided by the RFC, which received preferred stock. The other half of the necessary capital was provided by local interests, including General Motors and Chrysler, which were granted common stock in the company (New York Times 1933c). The RFC supervised the management of this new bank, the National Bank of Detroit.

The National Bank of Detroit immediately took control of the assets and liabilities of the Guardian group and the National group. On April 24, the National Bank of Detroit

\footnotetext{
${ }^{16}$ Equivalent to approximately $\$ 19.5$ billion in the year 2008 (Officer and Williamson, 2009).

${ }^{17}$ Equivalent to approximately $\$ 227$ million in the year 2008 (Officer and Williamson, 2009).

${ }^{18}$ This approach to measuring cost is now widely recognized. For example, the Emergency Economic Stabilization Act of 2008, which was the empowering legislation for the Troubled Asset Relief Program (TARP), requires the Congressional Budget Office (CBO) and Office of Management and Budget (OMB) to measure subsidies by including the cost of market risk when estimating the budgetary cost of TARP.

19 "Spokane sales" were used to dissolve banks that provided valuable services to the community but whose assets covered less than half of their debt. Conservators arranged the sale of "desirable assets in bulk...to an existing bank or a bank newly organized for that purpose," and creditors were immediately paid from the revenue generated by the sale (Kennedy 1973). After the sale and allocation of the proceeds, the old banks could be dissolved.
} 
distributed 30 percent of its holdings to the old depositors and began liquidating the assets of the Guardian and National groups in May. The efficiency of the RFC's "Detroit plan" spurred numerous applications for reorganization in other communities. In total, the RFC and Treasury Department authorized 257 similar relief operations. These rehabilitations were significant aspects of the repair begun with the passage of the Emergency Banking Act, which allowed the banking system to be rebuilt on stronger foundations following the banking crisis of 1933.

\section{Data Construction and Summary Statistics}

The purpose of this analysis is to measure the effect of the RFC's loan and preferred stock programs on bank failure rates, after controlling for other factors. The models use a cross-sectional set of bank-level data describing RFC loans and preferred stock investments in each bank, local economic conditions, individual bank financial characteristics, and the incidence and timing of bank failure.

Individual bank financial data come from the Federal Reserve member bank Reports of Condition and Income. For our period, regulators of state nonmember banks did not publish comparable and detailed data on individual banks' balance sheets, or earnings and expenses. Bank-level data for Fed member banks are available in the Reports of Condition and Income of the Federal Reserve, which were preserved only in part for our period (Mason 2001a, 1996). This means that our sample of banks is restricted to Federal Reserve member banks, and that the dates at which we observe financial information about all Fed member banks is restricted (we will rely on annual data observed in the December 1931 call report). Federal Reserve banks include all 
national banks and some (typically, the largest) state-chartered banks, which provides some institutional diversity in the sample. Our sample is roughly equally divided between national banks and state-chartered Fed member banks.

We collected detailed data on the individual characteristics of Michigan banks, as well as the characteristics of Michigan counties in which the banks operated. The database includes county-specific data on various aspects of the economic environment, as well as bank-specific data on bank balance sheet and income statement characteristics, dates of bank failure, the number of bank correspondent relationships of various kinds (which link the subject bank to banks operating elsewhere in the country), and the history of loans and preferred stock assistance each bank received from the RFC. Previous studies have identified bank and county characteristics that have been shown to be important either in forecasting failure risk or in determining access to RFC assistance, and those earlier studies informed our selection of variables for this study. We also include additional variables that have not been identified in earlier studies. The list of variables we employ are defined in Table 1, and the summary statistics for these variables are reported in Table 2.

Many Michigan banks relied on RFC loans prior to March 1933, and Michigan banks also made substantial and early use of the RFC's preferred stock program. As a result, Michigan banks provide a rich data set to examine the impact of RFC assistance. As shown in Table 3, of the 209 Michigan Fed member banks in our sample as of December 1931 (not all of which are included in our regression specifications due to some missing observations), 92 received RFC loans from March 1932 through February 1933. Of the 195 banks in the sample as of March 1933, 11 received preferred stock 
assistance in 1933 and another 43 received preferred stock assistance in 1934. (Three banks in the sample also received RFC loans after March 1933, but these are not included in Table 3 or in our regression analysis for the later period, as discussed further below.) Figure 1 provides a more detailed picture of the timing of the receipt of RFC loans and preferred stock assistance by Michigan banks in our sample.

As we have seen, the RFC played a central role in the reorganization of Detroit banking, through its assistance to the newly formed National Bank of Detroit. That observation, however, is not included in our database, because RFC assistance was provided in a special form as part of asset liquidation and the creation of a new bank. The predecessor and successor banks were separate entities. Our sample, in contrast, analyzes the effects of RFC loans and preferred stock assistance to open banks. Of course, given the potentially important stabilizing consequences of RFC assistance for the National Bank of Detroit, it is important to recognize that its omission from our sample unavoidably understates the systemic contribution of the RFC to Michigan banking.

The bank failure data for the national banks are taken from the Comptroller of the Currency's Annual Report. The Rand-McNally Bankers' Directory provides the failure data for state banks, supplemented in one case by an observation reported by the RFC. For the purposes of the analysis, receiverships and voluntary liquidations are treated as bank failures. Suspension and "conservatorship" are not treated as failure events. (Recall that all Michigan banks suspended in February of 1933, as required by law, and many banks received RFC assistance as part of their "conservatorship" to enable them to 
reopen.) Fifty seven of the banks in our sample failed, 7 of which received RFC loans and 4 of which received RFC preferred stock assistance. ${ }^{20}$

County-level data for most characteristics are taken from the Inter-university Consortium for Political and Social Research (ICPSR 2001) database. Additionally, we rely on Fishback and Kantor (2003) for county data on New Deal disbursements and loans. We collected data on each bank's correspondent relationships (number of correspondents in New York, Chicago, and elsewhere) from the Polk's Bankers' Encyclopedia. $^{21}$

RFC loans and preferred stock purchases were hand-coded from the monthly Reports of Activities of the Reconstruction Finance Corporation. ${ }^{22}$ The Reports include the amount of each loan and preferred stock purchase. Many banks received multiple loans or infusions of capital in the form of preferred stock. According to Mason (2001a), 32 percent of banks in the United States received more than one loan from the RFC and 12 percent borrowed from the government-sponsored entity more than twice. Previous studies have examined the average amount of each loan or preferred stock purchase by dividing the amount of each by the number of loans or preferred stock purchases (Friedman and Schwartz, 1963; Butkiewicz, 1995; Keehn and Smiley 1988, 1993). However, because so many banks received several loans or preferred stock purchases, the averages of RFC outlays may be biased downward.

\footnotetext{
${ }^{20}$ In Table 3, only 3 RFC recipients are shown as failures, owing to the nature of the timing described in the table, but one of the RFC preferred stock assistance recipients in 1933 failed in 1934.

${ }^{21}$ Almost all of the correspondent information was taken from the September 1931 issue of Polk's. In two cases, the subject bank was not listed in the September 1931 issue, and in those two cases we obtained correspondent information from the March 1932 issue.

${ }^{22}$ These reports were published when Congress was in session after fall 1932. The reports were reproduced in the Congressional Serial Set and, until 1933, in the Commercial and Financial Chronicle. The Archive of the Clerk of the House of Representatives preserved the reports submitted while Congress was in recess and remains the only source for these reports.
} 
Typically, a bank receiving one RFC loan received subsequent loans, as the loans were rolled over. This was not the case for preferred stock, which was typically received only once (all of our Michigan recipients received preferred stock assistance only once during the period March 1933-December 1934). In our study, we identify the date at which the bank received its first loan or its first preferred stock injection.

In measuring the effects of RFC preferred stock assistance we only include assistance received prior to the end of December 1934. We are aware that three banks in our sample received RFC preferred stock assistance in 1935, but failure risk was virtually nil in 1935 and 1936, so we do not consider assistance received during these years.

Our analysis treats the period January 1932-February 1933 separately from the period March 1933-December 1934. February 1933 is a natural dividing line for a separate two-period analysis of RFC assistance policies' effects in Michigan for two reasons. First, RFC policy changed from lending to preferred stock purchases in March 1933. Second, Michigan banks suspended in February 1933, and reopened from March 1933 through early February as part of the RFC/FDIC process of sorting institutions into the healthy (which could reopen without assistance, the curably sick (which received preferred stock assistance), and the dead (which were closed). In our regression analysis, therefore, the effects of RFC loans are estimated for the early failure period, while the effects of RFC stock purchases are estimated for the later period. As Table 3 shows, failure rates were higher for the later period; from January 1932 through February 1933, 
17 Michigan banks out of the 209 present as of December 1931 failed, while for the later period 40 out of 195 banks present as of March 1933 failed. ${ }^{23}$

Table 4 presents simple characteristic comparisons - analogous to those discussed in Calomiris and Mason (1997) for Chicago banks in the 1930s - across bank failure cohorts. Here we compare four groups of banks: those that failed in the early period (January 1932-February 1933), those that failed in the first part of the later period (March 1933-December 1933) during which many suspended banks were either closed or reopened, those that failed in the second part of the later period (January 1934-December 1934), and those that survived beyond December 1934.

The first characteristic we compare across these four groups is their exogenous ex ante failure risk. To capture exogenous ex ante failure risk we estimate a simple probit model of failure risk for the early period. The column labeled "Predicted failure" in Table 4 reports the estimated probability of failure from a probit model that is identical to the one reported in the first column of Table 5, except that RFC assistance is not included as an explanatory variable in the regression specification used to construct the predicted failure probabilities reported in Table 4. Clearly, and not surprisingly given the way predicted failure probabilities are constructed, the banks that failed in the period January 1932-February 1933 display the highest mean probability of failure (30.9\%). Predicted failure risk is lower for the other three sub-groups, and declines over time (from a mean of $7.3 \%$ for the banks that failed March-December 1933 to $6.2 \%$ for those that failed in 1934). Survivors had an average predicted failure risk of $3.9 \%$.

\footnotetext{
${ }^{23}$ Again, only 3 RFC recipients are shown as failures during Period 3 in Table 3, owing to the nature of the timing described in the table, but one of the RFC preferred stock assistance recipients in 1933 also failed in 1934.
} 
Table 4 also examines differences across the four cohorts in the structure of bank liabilities as of December 1931 and related differences in bank funding costs for 1931. As in Calomiris and Mason (1997), the differences are striking, and confirm that banks at greater risk of failure tended to experience a contraction in their demand deposits held by the public and in the deposits owed to other banks, and an expansion in their "Borrowed money" (a shorthand for bills payable and rediscounts as a proportion of total bank debt). In other words, as the market perceived banks to be at greater risk of default, demand deposits contracted and were replaced in part by higher-cost risky funding. That higher cost is reflected in the column labeled "Cost of funds" (defined as the total interest expense for 1931 divided by total debt). The cost of funds so defined averaged $4 \%$ for Michigan banks that ended up failing in the period January 1932-February 1933. For other banks, their average cost of funds in 1931 was roughly half as high.

The data reported in Tables 3 and 4 show that the connections between the receipt of RFC assistance and failure risk are potentially complex and must be analyzed carefully. As Table 3 indicates, roughly equal numbers of Michigan banks received or did not receive RFC loans in the early period, and the failure rate for the two groups was similar (9/94 and 8/118). This does not necessarily imply anything about the effectiveness of RFC loans in reducing failure risk, since the ex ante risk characteristics of recipients were not necessarily the same as those of non-recipients. Indeed, as Table 4 indicates, failed banks (which had higher ex ante failure risk) were more likely to receive RFC loans than banks that failed later or that survived. Similarly, only 4 out of 54 preferred stock issuing banks failed in the period March 1933-December 1934, compared to 23 out of 184 failures for non-recipients during 1933 and 13 out of 118 failures for 
banks that received no preferred stock assistance at any time in 1933 or 1934. Before reaching conclusions about the effectiveness of RFC preferred stock assistance, however, one must control for differences in the riskiness of banks targeted for assistance, and model the relationship between exogenous variation in RFC assistance and the consequences of that assistance for bank failure risk.

\section{Regression Methods and Empirical Results}

To analyze the relationship between RFC assistance of both types and bank failure risk we construct various regression models. We begin with simple probit and survival duration modeling of the consequences of RFC assistance. Loans are the form of RFC assistance in the early period and preferred stock purchases are the form of assistance in the later period. In these simple models, we consider the probability of failure over the specified period (in the probits) or the continuous survival duration hazard during the period as a function of the receipt of RFC assistance and various controls that capture the failure risk of the banks (based on 1931 bank characteristics and county characteristics). In the simple probit and survival models, reported in Tables 5 and $6, \mathrm{RFC}$ assistance takes a value of 1 if the bank receives assistance during the period and zero otherwise. In the case of the simple survival duration models, reported in Table 6, the receipt of assistance is related to the timing of subsequent failure (if any) within the period. In Table 5, we only examine failures within the relevant periods (ending in December 1934), while in Table 6 we utilize information about failure risk - which influences the shape of the survival duration function - through December 1936. 
When constructing a model of survival hazard, one has to choose the functional form of the survival function. We found that the choice between a log-logistic and a log normal functional forms did not affect our estimation results. For the sake of consistency, we report results for log normal specifications in Table 6 because using that approach permits us to perform subsequent estimation - which takes account of the endogeneity of RFC assistance - using bivariate tobit, joint maximum likelihood estimation (MLE) modeling, as we discuss further below.

The simple probit and survival models control for bank risk characteristics, but these estimates may still be biased due to the endogeneity of assistance to bank characteristics. In order to control for potential endogeneity bias, in subsequent regressions reported in Tables 7-10 we model the effects of RFC assistance using various regression procedures in which the first step forecasts the receipt of assistance and the second step estimates the effect of exogenous variation in assistance. The various twostage regression procedures we employ require the identification of "instruments" as well as "controls." Controls are variables that potentially affect both the probability of receiving RFC assistance and the probability of failure. Instruments are variables that are assumed to affect the probability of failure only (or at least primarily) through their effect on the probability of receiving assistance.

Probit models, which address the censoring and structural problems that arise in OLS estimation, do not address "the differences in time in which each person is at risk of experiencing the event" (Jenkins 2005). The statistical techniques used in survival analysis were developed to address "the sequential nature of the data, and are able to handle censoring and incorporate time-varying covariates" (Jenkins 2005). As a result, 
survival analysis allows us to incorporate the most information in our study of the relationship between RFC aid policies and bank failure rates. In the case of the bank survival times in this data set, duration is measured in days. Coefficients in the probit and survival models in Tables 5 and 6 should have opposite sign, as one measures the effect on failure risk, and the other measures the effect on the number of days of survival. We use a log-normal survival model. This differs slightly from the log-logistic parameterization taken by Calomiris and Mason (2003a), but coefficient estimates are nearly identical under either version, and the $\log$ normal structure facilitates MLE estimation (when addressing the endogeneity of assistance) using a bivariate tobit on the logarithm of survival days.

The bank characteristics selected as determinants of failure (controls) have been widely analyzed in the literature (Alston et al. 1994; Calomiris and Mason 1997, 2003a; Cole and Gunter 1995). Each bank characteristic is included at its value as of December 31, 1931. ${ }^{24}$ Net worth/total assets should be associated with lower failure risk. The riskier or less liquid a bank's assets, the greater its risk of failure. Bonds, stocks, securities owned, and loans and discounts are defined as risky and relatively "illiquid assets," and loans and discounts are distinguished from other illiquid assets, since they are likely to be particularly illiquid and risky. Paper eligible for rediscount at the Federal Reserve indicates lower credit risk assets which can produce greater liquidity (from Fed lending) and thus should be associated with a decreased risk of bank failure. "Real estate owned" indicates the level of foreclosed and nonperforming assets on the balance sheet of the bank, and should be associated with higher failure risk. Because interest and

\footnotetext{
${ }^{24}$ This analysis uses time-fixed covariates. Modeling these bank characteristics as time-varying covariates might better describe their effect on the likelihood of failure and bank failure rates.
} 
discount rates should be higher for riskier borrowers, the proportion of interest and discount income relative to earnings has sometimes proven to be a useful predictor of failure risk. Higher interest rate risk on liabilities compensate bank depositors and other debtholders for bearing higher expected default risk and thus should be associated with higher predicted failure rates. Recoveries, which may capture a sudden recovery in bank asset values following a macroeconomic downturn, may also be positively associated with failure risk. ${ }^{25}$ Larger bank size has been found to be associated with lower failure risk, reflecting potential gains from loan diversification or lower risks associated with locations in which banks are larger (bigger cities). National banks faced stricter limits on real estate lending than state-chartered bank and a different supervisory regime. We also include a county characteristic that Calomiris and Mason (2003a) identified as an important predictor of bank failure risk: the "Crop income share" in the county in 1930. This variable is meant to capture the extent to which banks are exposed to agricultural loan risk, which for the nation as a whole, was associated with greater risk of bank failure.

Given that these various controls are correlated, we do not expect all of them to prove significant in our regression specifications; nevertheless, because our main interest in including these variables is to control for differences in bank characteristics, we include them in our "Full" specifications reported in the various tables. We also report "Parsimonious" specifications that include a smaller list of variables that tend to prove significant in some of the reported specifications.

\footnotetext{
${ }^{25}$ Mason (2001a) notes, "recoveries may be positively associated with failure risk, if they capture a rebound in bank asset values following a trough."
} 
Our list of potential instruments - variables that are employed as exogenous determinants of RFC assistance that are not directly related to bank failure risk - includes attributes of the bank and the county that could have affected the supply or demand for RFC assistance for reasons unrelated to bank failure risk. The correspondent relationships of banks indicate the extent to which the bank was important within the national network of banking. It is possible that the RFC was more likely to approve assistance for banks that were regionally or nationally important. To capture this, we collected data on the number of correspondent relationships of each bank, and separately counted the number of correspondents in New York, Chicago, and elsewhere.

We regard correspondent relationships of Michigan banks as obvious candidates for valid instruments because they capture the extent to which problems suffered by Michigan banks might have threatened to spread elsewhere through the cashing in of Michigan banks' deposits held in other banks. Furthermore, Michigan banks' correspondent relationships should be orthogonal to the default risk of Michigan banks; they capture a one-directional liquidity risk that Michigan banks posed for other banks, not the liquidity risks of Michigan banks themselves (which we capture with other control variables in our default risk regressions).

For purposes of estimation, we divided relationships according to whether they involved money center banks in New York and Chicago, or other banks. For the same reason, we included the "Net due to banks over total assets" of each subject bank; it is possible that banks that were large creditors or debtors to other banks may have been regarded as more important by the RFC. Although we report results below only for "Net due to banks" we also experimented with including "Due to banks" and "Due from 
banks" separately, but these never proved significant. Similarly, we included an indicator variable for whether the bank was labeled an "Other reserve city bank" by the Fed.

As additional possible instruments, we also included county characteristics that might have affected RFC lending propensity: the size of the population in the county (larger counties may be more politically or economically important), the unemployment rate in the county in 1930, the proportion of suspended deposits in 1931 (deposits of failed banks), two measures of the extent to which the county received other forms of potentially relevant federal government assistance (the proportion of relief expenditures received by the county, and the proportion of government lending to the county that was related to the mortgage market), and the manufacturing employment share of the county. This latter variable - in the presence of the aforementioned control variable for crop income share - should not be directly relevant as a measure of bank default risk; rather, we included manufacturing employment as an indicator of the potential political or economic importance of the county.

\section{Simple Probits and Survival Duration Models}

In the simple probit models reported in Table 5, the illiquid asset ratio and the proportion of funding from bills payable and rediscounts proved to be the most robust and significant predictors of failure risk for both periods. In the later period, real estate owned and net worth also prove significant in the probits. Somewhat surprisingly, the national bank indicator variable has a positive sign in the probits, although it is challenging to interpret any partial correlation of a control variable given the correlations among control variables. Differences over time in the relevance of various covariates 
should be interpreted with caution. The fact that a characteristic was relevant for predicting failure in the early period may make it less relevant in the later period, because failed banks drop out of the sample used for estimation in the later period.

In the probit models reported in Table 5, RFC loans in the early period are negatively but insignificantly related to bank failure. Preferred stock purchases in the later period, in contrast, are negatively and significantly related to bank failure. These findings are consistent with the results of Mason (2001a), and with the hypothesized difference between the ineffectiveness of RFC loans (which increased bank indebtedness and subordinated depositors) and the effectiveness of RFC preferred stock assistance (which did not increase debt and did not subordinate depositors).

As in the probit analysis, illiquid assets tends to hasten failure (especially in the early period), real estate owned also hastens failure (in the later period), the proportion of funding in bills payable and rediscounts is associated with faster predicted failure, higher net worth prolongs failure (significantly so in the later period), and national banks (ceteris paribus) tend to fail faster than state member banks, ceteris paribus (in the later period). Also, as in the probit models, loan assistance in the early period has an insignificant positive effect in prolonging failure, while preferred stock assistance has a positive and statistically significant effect on prolonging failure.

\section{Controlling for the Endogeneity of RFC Assistance}

Because the likelihood of receiving RFC assistance is likely endogenous to the condition and circumstances of banks, there is a potential problem of endogeneity bias in 
the estimates reported in Tables 5 and 6 . To deal with this, we employ additional regression methods, using the instruments defined above.

In the context of the probit models, our approach to dealing with endogeneity follows Wooldridge (2002). This entails a three-stage process. First, we run a probit on the RFC indicator variable using controls and instruments to predict the probability of receiving RFC assistance. Next, we run a two-stage least squares model using the predicted values from the probit regression as the sole instrument.

The first-stage probit model is reported in Table 7. In addition to the significance of the some of the controls, we find that some of our instruments prove significant in predicting RFC assistance. The number of correspondent relationships robustly predicts RFC preferred stock assistance in the later period, and interestingly, correspondent connections to New York and Chicago enter positively in predicting assistance while total correspondent connections (including other locations) enter negatively; the implication is that only connections to money center banks had net positive effects on the probability of receiving RFC assistance. Corroborating that finding is the fact that a reserve city bank designation is also associated with a greater (marginally significant) likelihood of receiving assistance in the later period. County characteristics also prove useful as instruments. The proportion of employment in manufacturing is positively associated with RFC preferred stock assistance in the later period. Not all the county characteristics are easy to explain. Population size of the county has opposite, and significant, effects in the two sub-periods. A higher 1930 unemployment rate tends to decrease the probability of RFC assistance in both periods, but only in the full specifications. While this last finding may seem strange, one possible interpretation 
revolves around the importance of agricultural distress for unemployment in the early years of the Depression. This may simply be an indication that the RFC avoided assisting banks that were hit by severe agriculture-related problems in 1921-1930.

Table 8 reports the effects of instrumented RFC assistance on failure risk. Both versions of the model find that instrumented RFC assistance reduces failure risk in the later period. Although the Wooldridge (2002) approach for modeling the effect of instrumented RFC assistance on failure is inefficient compared to a bivariate probit, there are two reasons to use this approach rather than a bivariate probit. First, because of our small sample, the distribution of the error term in the first-stage probit is two-peaked (see Figure 2 (a)), and this makes it difficult for the bivariate probit model to converge. Second, the Wooldridge method permits us to compute various diagnostic statistics for our instruments; in contrast, we are unaware of any established statistical tests for the validity of instruments in the context of a bivariate probit model.

With respect to the power of our instruments, as we have noted, several of the instruments prove significant in the first-stage regressions. In the context of the Wooldridge (2002) approach, however, one can develop other tests of the validity and power of instruments, which are reported at the bottom of Table 8 . These tests indicate that the power of the instruments is greater in the full version of the model.

To deal with potential endogeneity problems in our survival modeling, we employed a bivariate tobit model, which exploits the fact that tobit is the appropriate functional form for estimating a log normal survival model. Thus, the dependent variables in Tables 9 and 10 should be interpreted, respectively, as the natural logarithm of days until receipt of RFC assistance and the days until failure. When comparing first- 
stage regression coefficients in Tables 7 and 9, coefficients on regressors should be of opposite sign. First-stage results in Table 9 are quite similar to those reported in Table 7. Some of the instruments gain significance in Table 9; in particular, mortgage loan assistance, which was not significant in Table 7, enters positively and somewhat significantly in Table 9.

Second-stage survival duration regressions are reported in Table 10. Coefficients on regressors should have opposite signs as those in Table 8, with the exception of the coefficient on the "Log of days to RFC assistance." That coefficient should, and does, have a negative sign for the later period in Table 10. This coefficient measures the effect on survival of the delay in receiving RFC assistance (the dependent variable in Table 9). The Log of days to RFC assistance is statistically significant, and confirms the result of Table 6. We only report results for three specifications in Table 10 because the results for the parsimonious survival model for the late period did not converge. This lack of convergence reflected a similar problem to the lack of convergence of the bivariate probit. In the early period survival models and in the full late-period model, convergence was not a problem, apparently because the error term had a less pronounced two-peaked shape (as shown in Figure 2 (b)).

\section{RFC Preferred Stock Effects on Lending By Survivors}

Finally, we investigate whether, conditional on survival, the receipt of RFC preferred stock over the period March 1933 through December 1934 increased the supply of loans and discounts for the period December 1931 through December 1935. We emphasize that our analysis understates the overall effect of RFC assistance on loan 
supply. Presumably, an important part of the effect of RFC assistance on loan supply resulted from mitigating the risk of bank failure, thereby increasing the supply of loans. Here we necessarily abstract from that important effect because we constrain the sample to banks that survived through December 1935 (the only ones for which lending is observed).

Furthermore, we emphasize that the effect of RFC preferred stock assistance on the loan supply of surviving banks, in theory, could be either positive or negative. On the one hand, the receipt of preferred stock assistance, per se, reduced insolvency risk and should have encouraged banks to lend more. On the other hand, the RFC required recipient banks to retain earnings and increase their capital ratios. The strings attached to RFC assistance could have caused recipients to reduce loan supply relative to surviving banks that did not receive assistance.

We report two alternative approaches to estimating the effect of RFC assistance on the lending by surviving banks. First, in Tables 11 and 12, we report results from the three-stage procedure suggested by Wooldridge (2002), described above. That is, we run a probit model for this sample (analogous to the regressions reported in Table 7), estimating the probability of receiving RFC preferred stock assistance for this sample. Those first-stage results are reported in Table 11, for both a full and parsimonious specification. Table 12 reports the two-stage least squares results for the loan growth regression, which uses the predicted values from Table 11 as the sole instrument. The dependent variable in Table 12 is bank loan growth from December 1931 to December 1935. 
It is important to emphasize that this exercise is performed on a constrained sample of bank survivors. Results in Table 11 consequently are quite different from those in Table 7. FERA assistance now comes in significant in the first-stage regression, as does the manufacturing employment share, but not the numbers of correspondents or the reserve city bank indicator.

It is also important to emphasize that we would expect that FERA assistance and the manufacturing employment share may be correlated with loan demand, and thus, it is not obvious on an a priori basis that these are valid instruments for a second-stage regression of loan growth. We report various tests of instrument power at the bottom of Table 12. They confirm that the instruments are powerful for the full model, but not as much for the parsimonious model (for example, the Cragg-Donald Wald F statistic is 4.30, which is far below the Stock-Yogo $10 \%$ critical value of 16.38).

The second approach we employ to measuring loan-supply effects uses MLE estimation, reported in Tables 13 and 14. We run the first stage alternatively as a probit or a tobit and the second stage as an OLS. We were not able to estimate the full probit model, once again, because of convergence problems, and so only three versions of the results are reported in the two tables. In any case, we regard the full tobit results as preferable, owing to the superiority of the continuous functional form, and to the greater power of the instruments in the full model.

The reason we report the MLE alternative to the Wooldridge approach is that it is possible that its greater efficiency from correctly specified functional forms will improve the power of the instruments and the implied statistical significance of the estimates of the effects of RFC assistance. Indeed, this is what we find. The coefficient estimates in 
the first row of Table 14 increase in magnitude and significance in the MLE estimation compared to those in Table 12, including for the parsimonious specification, for which the validity of the instruments is clearer. We conclude that the apparently low power of instruments in the parsimonious specification of Table 12 reflects the inefficiency of the Wooldridge procedure relative to MLE. We conclude that RFC preferred stock assistance substantially increased the loan supply of recipient banks, even after conditioning on their survival. The estimated coefficient magnitudes of the effect of RFC assistance on loan growth reported in Table 14 are large. For example, according to the parsimonious probit specification, surviving RFC recipients display loan growth over the period that is $93 \%$ higher than surviving non-recipients.

\section{$\underline{\text { V. Conclusion }}$}

The operations of the Reconstruction Finance Corporation in Michigan during the Great Depression provide an opportunity to investigate the effects of government loan and preferred stock programs on distressed financial institutions during a time of substantial failure risk. Our time period - January 1932 through December 1934 - covers an early period in which bank failures occurred in a scattered time pattern during which the RFC made loans to assist banks, and a later period in which failures were concentrated in time and coincided with regional and national panics during which the RFC purchased banks' preferred stock to assist them.

The empirical analysis suggests that collateralized short-term loans from the RFC made bank failure no less likely, and possibly made it more likely, while direct recapitalizations in the form of preferred stock injections increased the likelihood of bank 
survival. The preferred stock program owed its success to several factors: (1) It did not burden the bank with increased debt, increased liquidity risk, or collateral requirements that subordinated the claims of depositors, (2) the RFC was selective, and apparently chose viable cases, not basket cases, when granting assistance, and (3) the RFC implemented effective measures to ensure that government assistance was not abused by banks receiving assistance. These results suggest that during a banking crisis, effective assistance requires the government to assume a significant share of the risk of bank failure.

Our results are robust to controlling for potential endogeneity bias by modeling the determinants of RFC assistance alongside the determinants of failure. In doing so we are able to identify several instruments that predict RFC assistance, including the importance of the subject bank to the national network of banks. Michigan banks with a greater number of correspondent relationships with money-center banks, or which were "other reserve city" banks, were more likely to receive assistance than other banks. Furthermore, banks located in counties with a greater proportion of manufacturing employment, and with other harder to interpret county attributes, also were more likely to receive assistance.

We also explore the links between RFC assistance and loan supply. The sizes of estimates effects on loan growth over the period 1931 to 1935 are large, even after conditioning on bank survival.

Our results reinforce the conclusions of earlier work on the effects of RFC assistance in Illinois by Mason (1996, 2001a, 2001b, 2003) and Calomiris and Mason (2004). That comparison is important because Illinois banks' experience differed from 
Michigan's later and more severe banking problems. Furthermore, our empirical estimation techniques improve upon the list of instruments and the econometric efficiency of earlier estimates, which accounts for the fact that we are able to find large and statistically significant effects of RFC preferred stock assistance not only on bank failure risk but also on the loan supply of surviving banks. Earlier research for Illinois had found positive and insignificant loan-supply effects; our estimated effects on loan supply are larger and statistically significant. 


\section{References}

Alston, Lee J., Wayne A. Grove, and David C. Wheelock. "Why Do Banks Fail? Evidence from the 1920s." Explorations in Economic History 31, October 1994, 409-31.

Awalt, Francis Gloyd. "Recollections of the Banking Crisis in 1933." The Business History Review, 43 (3), 1969, 347-71.

Butkiewicz, James L. "The Impact of a Lender of Last Resort during the Great Depression: The Case of the Reconstruction Finance Corporation." Explorations in Economic History 32, April 1995, 197-216.

Calomiris, Charles W. "The Political Lessons of Depression-Era Banking Reform," Oxford Review of Economic Policy, 26, 2010, 540-560.

Calomiris, Charles W. "Contagion and Bank Failures during the Great Depression: The June 1932 Chicago Banking Panic." American Economic Review 87, December 1997, 863-83.

Calomiris, Charles W., and Joseph R. Mason. "Fundamentals, Panics and Bank Distress During the Depression," American Economic Review, 93, December 2003, 161547.

Calomiris, Charles W. and Joseph R. Mason. "Consequences of U.S. Bank Distress During the Depression," American Economic Review 93, June 2003b, 937-947.

Calomiris, Charles W. and Joseph R. Mason. "How to Restructure Failed Banking Systems: Lessons from the U.S. in the 1930s and Japan in the 1990s," in Governance, Regulation, and Privatization in the Asia-Pacific Region, Takatoshi Ito and Anne Krueger, eds., NBER, University of Chicago Press, 2004, 375-420.

Calomiris, Charles W. and Eugene N. White. "The Origins of Federal Deposit Insurance," in The Regulated Economy: A Historical Approach to Political Economy, C. Goldin and G. Libecap, eds., NBER, University of Chicago Press, 1994, 145-88.

Cole, Rebel A. and Jeffery W. Gunther. "Separating the Likelihood and Timing of Bank Failure." Journal of Banking and Finance 19, September 1995, 1073-89.

Comptroller of the Currency. Annual Report. Washington, DC: U.S. Government Printing Office, various years.

Federal Deposit Insurance Corporation. "A History of the FDIC 1933-1983." http://www.fdic.gov/bank/analytical/firstfifty/index.html. 
Federal Reserve Board. Banking and Monetary Statistics, 1914-1941. Washington, DC: Federal Reserve Board, 1943.

Friedman, Milton and Anna Jacobson Schwartz, eds. A Monetary History of the United States, 1867-1960. Princeton, New Jersey: Princeton University Press, 1963.

Gourieroux, Christian, Alain Monfort, Eric Renault, and Alain Trognon. "Generalised Residuals." Journal of Econometrics 34, no. 1-2 (1987): 5-32.

Inter-university Consortium for Political and Social Research (2001). "Historical, Demographic, Economic, and Social Data: The United States, 1790-1970," http://www.icpsr.umich.edu/icpsrweb/ICPSR/studies/3/documentation.

James, F. Cyril. The Growth of Chicago Banks, vol 2. New York: Harper and Brothers, 1938.

Jenkins, Stephen P. “Survival Analysis: Lecture Notes.” University of Essex, July 2005.

Jones, Jesse H. and Carl Howard Pforzheimer. Fifty Billion Dollars: My Thirteen Years with the RFC, 1932-1945. New York: Macmillan, 1951.

Price Fishback and Shawn Kantor. "Can the New Deal's Three R's Be Rehabilitated? A Program-by-Program, County-by-County Analysis," with Shawn Kantor and John Wallis. Explorations in Economic History, October 2003, 278-307.

Keehn, Richard H. and Gene Smiley. "U.S. Bank Failures, 1932-1933: A Provisional Analysis." Essays in Economic and Business History 4, 1988, 136-56.

Keehn, Richard H and Gene Smiley. "U.S. Bank Failures, 1932-1933: Additional Evidence on Regional Patterns, Timing, and the Role of the Reconstruction Finance Corporation." Essays in Economic and Business History 11 (1993), 13145.

Kennedy, Susan Estabrook. The Banking Crisis of 1933. Lexington, Kentucky: University Press of Kentucky, 1973.

Lohr, Steve. "Intervention Is Bold, but Has a Basis in History." New York Times, October $13,2008$.

Los Angeles Times. "Ford Backs Two Banks.” February 27, 1933, 1.

Mason, Joseph R. "The Political Economy of Reconstruction Finance Corporation Assistance during the Great Depression." Explorations in Economic History 40 (2), 2003, 101-21. 
Mason, Joseph R. "Do Lender of Last Resort Policies Matter? The Effects of Reconstruction Finance Corporation Assistance to Banks during the Great Depression." Journal of Financial Services Research 20 (1), 2001a, 77-95.

Mason, Joseph R. "Reconstruction Finance Corporation Assistance to Financial Intermediaries and Commercial and Industrial Enterprises in the United States, 1932-37." In Stijn Claessens, Simeon Djankov, and Ashoka Mody, eds. Resolution of Financial Distress: An International Perspective on the Design of Bankruptcy Laws. Washington, D.C.: The World Bank Group, 2001b, 167-204.

Mason, Joseph R. "The Determinants and Effects of Reconstruction Finance Corporation Assistance to Banks during the Great Depression." Doctoral dissertation, University of Illinois at Urbana-Champaign, 1996.

New York Times. "Ford's Bank Action Told.” February 15, 1933a, 2.

New York Times. "Michigan Bankers Act to Reorganize." February 23, 1933b, 12.

New York Times. “R.F.C. Acts to Spur Bank Reopenings.” March 21, 1933c, C25.

New York Times. “Detroit Rejects 'Wall Street' Aid.” February 19, 1933d, 21.

New York Times. "Detroit Banks Face Hitch in Loan Here.” March 1, 1933e, 5.

New York Times. "New Detroit Banks Formed.” February 25, 1933f, 21, 25.

New York Times. "Scrip is Planned for Use in Detroit." February 26, 1933 g, N7.

Officer, Lawrence H. and Samuel H. Williamson, "Purchasing Power of Money in the United States from 1774 to 2008," MeasuringWorth, 2009. http://www.measuringworth.com/ppowerus/

Olson, James S. Herbert Hoover and the Reconstruction Finance Corporation, 19311933, 1st ed. Ames: Iowa State University Press, 1977.

Olson, James S. "The End of Voluntarism: Herbert Hoover and the National Credit Corporation.” Annals of Iowa 41, Fall 1972, 1104-13.

Polk's Bankers' Encyclopedia. R.L. Polk and Co.: New York. Various issues, September 1931-March 1932.

Rand-McNally Bankers' Directory. Rand McNally: Chicago. Various issues, 1929-1936. 
"Report of Activities of the Reconstruction Finance Corporation" (monthly, unpublished). National Archives, Records of the Clerk of the House of Representatives, various issues.

"Reports of Condition and Income of Federal Reserve Member Banks" (unpublished reports, Microfilm). Washington, DC: Federal Reserve Board, 1931-1935.

US House of Representatives. Hearings before the Committee on Banking and Currency, 7Ist Congress, 2nd Session, under H. Res. 141, 1930, Volume 1, pp. 163-84 and 469-70.

White, Eugene N. "The Legacy of Deposit Insurance: The Growth, Spread, and Cost of Insuring Financial Intermediaries," in The Defining Moment: The Great Depression and the American Economy in the Twentieth Century, M. D. Bordo, C. Goldin, and E. N. White, eds., NBER, University of Chicago Press, 1998, 87124.

Wooldridge, J.M. Econometric Analysis of Cross Section and Panel Data. Cambridge: MIT Press, 2002. 


\section{Table 1: Variable Definitions}

\begin{tabular}{|c|c|}
\hline National bank dummy & Bank is a national bank ( $1=\mathrm{Yes}, 0=\mathrm{No})$ \\
\hline Other reserve city bank & Bank is in a non-central reserve city $(1=\mathrm{Yes}, 0=\mathrm{No})$ \\
\hline Total assets & Total bank assets \\
\hline Illiquid assets & $\begin{array}{l}\text { Total assets - US gov. securities - Reserves with Fed - Cash and due } \\
\text { from banks - Outside checks and other cash items }\end{array}$ \\
\hline Illiquid assets over total assets & Illiquid assets divided by total assets \\
\hline Real estate owned over illiquid assets & Real estate owned other than banking house divided by illiquid assets \\
\hline Loans and discounts over illiquid assets & Loans and discounts divided by illiquid assets \\
\hline Net worth over total assets & Bank net worth over total assets \\
\hline Total debt & $\begin{array}{l}\text { Due to Banks + Demand Deposits + Time Deposits + US Government } \\
\text { Deposits +Bills Payable and Rediscounts }\end{array}$ \\
\hline Bills payable and rediscounts over total debt & Bills Payable and Rediscounts divided by total debt \\
\hline Demand deposits and due to banks over total debt & (Demand deposits + Due to banks) divided by total assets \\
\hline Net due to banks over total assets & (Due to banks - due from banks) divided by total assets \\
\hline Interest cost over total debt & Interest expense divided by total debt \\
\hline Loans eligible for rediscount over total loans and discounts & Loans eligible for rediscount at the Fed divided by total loans \\
\hline Interest and discounts on loans over total earnings & Interest and discount on loans divided by total earnings \\
\hline Recoveries over total earnings & Total recoveries divided by total earnings \\
\hline Losses over total expenses & Total losses divided by total expenses \\
\hline Crop income share in county in 1930 & $\begin{array}{l}\text { Value of crops divided by sum of value of crops }+ \text { value added by } \\
\text { manufacturing }\end{array}$ \\
\hline Total number of correspondents & Total number of correspondent relationships \\
\hline Number of correspondents in New York and Chicago & Number of correspondent relationships in New York and Chicago \\
\hline County population in 1930 & Total population in the county in 1930 \\
\hline Unemployment rate for county in 1930 & Unemployment rate for the county in 1930 \\
\hline Suspended deposits share of 1931 county deposits & $\begin{array}{l}\text { (Suspended deposits in } 1930+\text { Suspended deposits in 1931) divided by } \\
\text { total deposits in } 1931\end{array}$ \\
\hline Mortgage loan share of total loans for county & Amount of mortgage loans divided by total loans for the county \\
\hline FERA share of grants for county & Amount of FERA grants divided by total grants for county \\
\hline Manufacturing employment share in county in 1930 & $\begin{array}{l}\text { Number of wage earners in manufacturing divided by total number of } \\
\text { gainful workers in county }\end{array}$ \\
\hline Loan growth Dec 1935 - Dec 1931 & $\begin{array}{l}\text { In (Loans and discounts Dec } 31 \text { 1935) - In (loans and discounts Dec } 31 \\
\text { 1931) }\end{array}$ \\
\hline
\end{tabular}


Table 2: Summary statistics

\begin{tabular}{|c|c|c|c|c|c|c|}
\hline Variable & mean & median & sd & $\min$ & $\max$ & $\mathbf{N}$ \\
\hline Total assets & $6,829,000$ & $1,099,000$ & $42,620,000$ & 110,635 & $582,300,000$ & 209 \\
\hline Illiquid assets over total assets & 0.826 & 0.833 & 0.086 & 0.322 & 0.978 & 209 \\
\hline Real estate owned over illiquid assets & 0.0152 & 0.00911 & 0.0188 & 0 & 0.126 & 209 \\
\hline Net worth over total assets & 0.13 & 0.124 & 0.0407 & 0.0344 & 0.332 & 209 \\
\hline Bills payable and rediscounts over total debt & 0.0474 & 0.0286 & 0.0563 & 0 & 0.288 & 209 \\
\hline National bank dummy & 0.493 & 0 & 0.501 & 0 & 1 & 209 \\
\hline Demand deposits and due to banks over total debt & 0.261 & 0.231 & 0.139 & 0 & 0.981 & 209 \\
\hline Loans and discounts over illiquid assets & 0.584 & 0.606 & 0.159 & 0.132 & 0.917 & 209 \\
\hline Loans eligible for rediscount over total loans and discounts & 0.156 & 0.131 & 0.123 & 0 & 0.688 & 209 \\
\hline Interest cost over total debt & 0.0237 & 0.0135 & 0.0398 & 0.0000 & 0.323 & 204 \\
\hline Interest and discounts on loans over total earnings & 0.593 & 0.591 & 0.201 & 0.0803 & 0.992 & 204 \\
\hline Recoveries over total earnings & 0.0208 & 0.00146 & 0.0464 & 0 & 0.277 & 204 \\
\hline Losses over total expenses & 0.242 & 0.209 & 0.202 & 0 & 0.787 & 205 \\
\hline Crop income share in county in 1930 & 0.978 & 0.997 & 0.0703 & 0.656 & 1 & 202 \\
\hline Total number of correspondents & 3.756 & 3 & 3.65 & 1 & 37 & 209 \\
\hline Number of correspondents in New York and Chicago & 1.88 & 2 & 1.383 & 0 & 11 & 209 \\
\hline County population in 1930 & 140,739 & 49,849 & 375,707 & 8,451 & $1,889,000$ & 209 \\
\hline Unemployment rate for county in 1930 & 0.0789 & 0.0771 & 0.0296 & 0.0218 & 0.137 & 209 \\
\hline Suspended deposits share of 1931 county deposits & 0.287 & 0.107 & 0.459 & 0 & 2.871 & 209 \\
\hline Net due to banks over total assets & -0.0267 & -0.0195 & 0.0316 & -0.158 & 0.0962 & 208 \\
\hline Mortgage loan share of total loans for county & 0.434 & 0.439 & 0.13 & 0.169 & 0.664 & 209 \\
\hline Other reserve city bank & 0.0383 & 0 & 0.192 & 0 & 1 & 209 \\
\hline FERA share of grants for county & 0.175 & 0.177 & 0.0574 & 0.0502 & 0.283 & 209 \\
\hline Manufacturing employment share in county in 1930 & 0.174 & 0.137 & 0.12 & 0.00518 & 0.474 & 209 \\
\hline Loan growth Dec 1935 - Dec 1931 & -0.651 & -0.648 & 0.527 & -2.146 & 1.489 & 116 \\
\hline
\end{tabular}


Table 3: Banks receiving RFC loans and preferred stock assistance, and their failure outcomes

\begin{tabular}{|c|c|c|c|c|c|}
\hline & $\begin{array}{l}\text { \# of banks at } \\
\text { beginning }\end{array}$ & $\begin{array}{c}\text { \# of RFC assistance } \\
\text { recipients }\end{array}$ & $\begin{array}{l}\text { \# of RFC assistance } \\
\text { recipients that } \\
\text { failed }\end{array}$ & $\begin{array}{c}\text { \# of RFC assistance } \\
\text { non-recipients }\end{array}$ & $\begin{array}{c}\text { \# of RFC assistance } \\
\text { non-recipients that } \\
\text { failed }\end{array}$ \\
\hline Period 1 & $01 / 32$ & $03 / 32-02 / 33$ & $03 / 32-02 / 33$ & $03 / 32-02 / 33$ & $03 / 32-02 / 33$ \\
\hline Loans & 212 & 94 & 9 & 118 & 8 \\
\hline Period 2 & $03 / 33$ & $03 / 33-12 / 33$ & $03 / 33-12 / 33$ & $03 / 33-12 / 33$ & $03 / 33-12 / 33$ \\
\hline Preferred stock & 195 & 11 & 0 & 184 & 23 \\
\hline Period 3 & $01 / 34$ & $01 / 34-12 / 34$ & $01 / 34-12 / 34$ & $03 / 33-12 / 34$ & $01 / 34-12 / 34$ \\
\hline Preferred stock & 172 & 43 & 3 & 118 & 13 \\
\hline
\end{tabular}


Table 4: Ex ante failure risk, liability structure, and funding cost for different bank failure cohorts

\begin{tabular}{|c|c|c|c|c|c|c|c|c|}
\hline GROUP & Statistic & $\begin{array}{l}\text { Predicted } \\
\text { failure }\end{array}$ & $\begin{array}{l}\text { Demand } \\
\text { deposits }\end{array}$ & $\begin{array}{l}\text { Due to } \\
\text { banks }\end{array}$ & $\begin{array}{c}\text { Time } \\
\text { deposits }\end{array}$ & $\begin{array}{c}\text { Borrowed } \\
\text { Money }\end{array}$ & $\begin{array}{l}\text { Cost of } \\
\text { funds }\end{array}$ & $\begin{array}{l}\% \text { RFC } \\
\text { loans }\end{array}$ \\
\hline \multirow{3}{*}{$\begin{array}{c}\text { Failed } \\
\text { Jan } 32 \text { - Feb } 33\end{array}$} & Mean & 0.309 & 0.140 & 0.006 & 0.767 & 0.087 & 0.041 & 0.500 \\
\hline & Variance & 0.234 & 0.115 & 0.009 & 0.130 & 0.063 & 0.077 & 0.522 \\
\hline & $\mathrm{N}$ & 12 & 12 & 12 & 12 & 12 & 12 & 12 \\
\hline \multirow{3}{*}{$\begin{array}{c}\text { Failed } \\
\text { Mar } 33-\text { Dec } 33\end{array}$} & Mean & 0.073 & 0.300 & 0.020 & 0.620 & 0.061 & 0.013 & 0.783 \\
\hline & Variance & 0.125 & 0.177 & 0.037 & 0.187 & 0.052 & 0.007 & 0.422 \\
\hline & $\mathrm{N}$ & 23 & 23 & 23 & 23 & 23 & 23 & 23 \\
\hline \multirow{3}{*}{$\begin{array}{c}\text { Failed } \\
\text { Jan } 34-\text { Dec } 34\end{array}$} & Mean & 0.062 & 0.240 & 0.007 & 0.676 & 0.075 & 0.020 & 0.750 \\
\hline & Variance & 0.090 & 0.086 & 0.009 & 0.114 & 0.064 & 0.020 & 0.447 \\
\hline & $\mathrm{N}$ & 16 & 16 & 16 & 16 & 16 & 16 & 16 \\
\hline \multirow[t]{3}{*}{ Survivors } & Mean & 0.039 & 0.251 & 0.011 & 0.693 & 0.037 & 0.024 & 0.331 \\
\hline & Variance & 0.080 & 0.129 & 0.017 & 0.139 & 0.050 & 0.041 & 0.472 \\
\hline & $\mathrm{N}$ & 145 & 145 & 145 & 145 & 145 & 145 & 145 \\
\hline \multirow[t]{3}{*}{ Means tests } & Diff 1-4 & $0.2693 * * *$ & $-0.111 * * *$ & -0.0048 & $0.0734 *$ & $0.0503 * *$ & 0.0169 & 0.169 \\
\hline & Diff 2-4 & 0.0339 & 0.0489 & 0.0085 & $-0.0736^{*}$ & $0.0236 * *$ & $-0.0113 * * *$ & $0.4516^{* * *}$ \\
\hline & Diff 3-4 & 0.0231 & -0.0113 & -0.004 & -0.0167 & $0.0376 * *$ & -0.004 & $0.419 * * *$ \\
\hline
\end{tabular}


Table 5: Simple probit model. Dep Var = Failure dummy $(0,1)$.

\begin{tabular}{|c|c|c|c|c|}
\hline VARIABLES & $\begin{array}{c}\text { Jan32 - Feb33 } \\
\text { Full }\end{array}$ & $\begin{array}{l}\text { Jan32 - Feb33 } \\
\text { Parsimonious }\end{array}$ & $\begin{array}{c}\text { Mar33 - Dec34 } \\
\text { Full }\end{array}$ & $\begin{array}{r}\text { Mar33 - Dec34 } \\
\text { Parsimonious }\end{array}$ \\
\hline \multirow[t]{2}{*}{ RFC assistance dummy } & -0.4029 & -0.1629 & $-1.0593 * * *$ & $-1.0006 * * *$ \\
\hline & $(0.4556)$ & $(0.3489)$ & $(0.3508)$ & $(0.3264)$ \\
\hline \multirow[t]{2}{*}{ Log of total assets } & 0.0420 & -0.0444 & -0.0624 & 0.0876 \\
\hline & $(0.2083)$ & $(0.1634)$ & $(0.1259)$ & $(0.0916)$ \\
\hline \multirow[t]{2}{*}{ Illiquid assets over total assets } & $11.2078 * * *$ & $10.2089 * * *$ & $3.8240^{*}$ & 0.6808 \\
\hline & (3.9898) & $(3.4380)$ & $(2.0210)$ & $(2.0452)$ \\
\hline \multirow[t]{2}{*}{ Real estate owned over illiquid assets } & 5.1431 & 5.6048 & $10.5144 *$ & $16.6746 * * *$ \\
\hline & $(7.9620)$ & (6.3436) & $(6.1663)$ & $(5.7026)$ \\
\hline \multirow[t]{2}{*}{ Net worth over total assets } & -3.4871 & -2.3116 & $-7.9845 * *$ & $-6.1968 *$ \\
\hline & $(5.6201)$ & (3.9926) & (3.7608) & $(3.3610)$ \\
\hline \multirow[t]{2}{*}{ Bills payable and rediscounts over total debt } & $6.3771 * *$ & $7.0124 * * *$ & $5.4288 * *$ & $5.9379 * *$ \\
\hline & $(2.9894)$ & $(2.2730)$ & $(2.3866)$ & $(2.3236)$ \\
\hline \multirow[t]{2}{*}{ National bank dummy } & $0.8782^{*}$ & 0.3370 & $1.9263 * * *$ & $1.5940 * * *$ \\
\hline & $(0.4491)$ & $(0.3194)$ & $(0.3604)$ & $(0.3159)$ \\
\hline \multirow[t]{2}{*}{ Demand deposits and due to banks over total debt } & -1.6362 & & $2.0368^{*}$ & \\
\hline & $(2.7259)$ & & $(1.1625)$ & \\
\hline \multirow[t]{2}{*}{ Loans and discounts over illiquid assets } & $2.2689 *$ & & 1.0122 & \\
\hline & $(1.1649)$ & & $(1.0407)$ & \\
\hline \multirow[t]{2}{*}{ Loans eligible for rediscount over total loans and discounts } & -1.2912 & & -0.7461 & \\
\hline & $(1.7630)$ & & $(1.1701)$ & \\
\hline \multirow[t]{2}{*}{ Interest cost over total debt } & 3.6971 & & -0.3177 & \\
\hline & $(3.0678)$ & & $(3.0231)$ & \\
\hline \multirow[t]{2}{*}{ Interest and discounts on loans over total earnings } & 0.2649 & & 0.4251 & \\
\hline & $(0.7351)$ & & $(0.8522)$ & \\
\hline \multirow[t]{2}{*}{ Recoveries over total earnings } & -7.9374 & & $-5.2796^{*}$ & \\
\hline & $(5.7580)$ & & $(3.0003)$ & \\
\hline \multirow[t]{2}{*}{ Losses over total expenses } & $-2.2976 * *$ & & 0.2828 & \\
\hline & $(0.9062)$ & & $(0.6626)$ & \\
\hline \multirow[t]{2}{*}{ Crop income share in county in 1930} & 16.2310 & & -1.7413 & \\
\hline & $(14.3842)$ & & $(2.2902)$ & \\
\hline \multirow{2}{*}{ Constant } & $-28.9016 * *$ & $-10.0873 * * *$ & -2.9938 & -3.1971 \\
\hline & $(14.1344)$ & $(3.2302)$ & $(3.4864)$ & $(2.5201)$ \\
\hline Pseudo R2 & 0.377 & 0.282 & 0.352 & 0.303 \\
\hline Log-likelihood & -28.13 & -36.87 & -61.61 & -68.96 \\
\hline Log-likelihood constant only & -45.14 & -51.37 & -95.04 & -98.95 \\
\hline LR Chi-2 test for zero coefficients (pval) & $4.14 \mathrm{e}-05$ & 0.000171 & $2.49 e-06$ & $3.28 \mathrm{e}-08$ \\
\hline Number of banks & 196 & 209 & 184 & 195 \\
\hline Number of failures & 12 & 14 & 39 & 40 \\
\hline Number of banks receiving RFC assistance & 84 & 92 & 50 & 54 \\
\hline
\end{tabular}


Table 6: Simple log-normal duration model. Dep Var = log (days to failure).

\begin{tabular}{|c|c|c|c|c|}
\hline VARIABLES & $\begin{array}{c}\text { Jan32 - Feb33 } \\
\text { Full }\end{array}$ & $\begin{array}{l}\text { Jan32 - Feb33 } \\
\text { Parsimonious }\end{array}$ & $\begin{array}{c}\text { Mar33 - Dec36 } \\
\text { Full }\end{array}$ & $\begin{array}{c}\text { Mar33 - Dec36 } \\
\text { Parsimonious }\end{array}$ \\
\hline \multirow[t]{2}{*}{ RFC assistance dummy } & 0.8540 & 0.4402 & $1.6467 * * *$ & $1.7097^{* * *}$ \\
\hline & $(0.6054)$ & $(0.5130)$ & $(0.4815)$ & $(0.4961)$ \\
\hline \multirow[t]{2}{*}{ Log of total assets } & 0.0006 & 0.0946 & 0.0029 & $-0.2107^{*}$ \\
\hline & $(0.2881)$ & $(0.2355)$ & $(0.1653)$ & $(0.1277)$ \\
\hline \multirow[t]{2}{*}{ Illiquid assets to total assets } & $-14.4457 * * *$ & $-14.7900 * * *$ & -4.0628 & 0.2773 \\
\hline & $(5.4293)$ & $(5.0424)$ & $(2.4748)$ & $(2.9952)$ \\
\hline \multirow[t]{2}{*}{ Real estate owned to illiquid assets } & -9.3540 & -11.2892 & $-13.4654^{*}$ & $-24.0576 * * *$ \\
\hline & $(10.2992)$ & $(10.2457)$ & $(6.9177)$ & $(6.8557)$ \\
\hline \multirow[t]{2}{*}{ Net worth over total assets } & 9.3406 & 4.7992 & $9.8151 * *$ & $8.9359 *$ \\
\hline & (6.7888) & $(5.8220)$ & $(4.9501)$ & $(5.0665)$ \\
\hline \multirow[t]{2}{*}{ Bills payable and rediscounts over total debt } & $-7.9487 * *$ & $-9.9201 * * *$ & $-7.6245 * * *$ & $-8.8869 * * *$ \\
\hline & $(3.9173)$ & $(3.1463)$ & $(2.9549)$ & $(2.9139)$ \\
\hline \multirow[t]{2}{*}{ National bank dummy } & $-1.0821^{*}$ & -0.3616 & $-2.7188 * * *$ & $-2.4390 * * *$ \\
\hline & $(0.5767)$ & $(0.4076)$ & $(0.4230)$ & $(0.4177)$ \\
\hline \multirow[t]{2}{*}{ Demand deposits and due to banks over total debt } & 3.0034 & & $-2.5626^{*}$ & \\
\hline & $(3.4893)$ & & $(1.4795)$ & \\
\hline \multirow[t]{2}{*}{ Loans and discounts to illiquid assets } & $-2.8684^{*}$ & & -0.9896 & \\
\hline & $(1.6255)$ & & $(1.4299)$ & \\
\hline \multirow[t]{2}{*}{ Loans eligible for rediscount over total loans and discounts } & 1.4367 & & 0.6556 & \\
\hline & $(2.1776)$ & & $(1.5063)$ & \\
\hline \multirow[t]{2}{*}{ Interest cost over total debt } & -4.8160 & & 0.4407 & \\
\hline & $(4.0975)$ & & $(4.6608)$ & \\
\hline \multirow[t]{2}{*}{ Interest and discounts on loans over total earnings } & -0.7265 & & -0.6225 & \\
\hline & $(1.0266)$ & & $(1.2018)$ & \\
\hline \multirow[t]{2}{*}{ Recoveries over total earnings } & 9.0121 & & $6.8541^{*}$ & \\
\hline & $(6.2040)$ & & $(4.0151)$ & \\
\hline \multirow[t]{2}{*}{ Losses over total expenses } & $2.5930^{*}$ & & 0.0873 & \\
\hline & $(1.3917)$ & & $(0.8856)$ & \\
\hline \multirow[t]{2}{*}{ Crop income share in county in 1930} & -12.7862 & & 3.5165 & \\
\hline & $(19.3692)$ & & $(2.5401)$ & \\
\hline \multirow[t]{2}{*}{ Constant } & $33.9623^{*}$ & $20.0639 * * *$ & $10.1937 * *$ & $12.0517^{* * *}$ \\
\hline & $(19.1707)$ & $(5.0586)$ & $(4.5412)$ & $(3.7548)$ \\
\hline \multirow[t]{2}{*}{ In_gam } & $0.3029 * *$ & $0.4283^{* *}$ & $0.3991 * * *$ & $0.4745^{* * *}$ \\
\hline & $(0.1399)$ & $(0.1754)$ & $(0.0978)$ & $(0.0892)$ \\
\hline Log-likelihood & -38.05 & -49.25 & -111.2 & -119.8 \\
\hline Log-likelihood constant only & -56.28 & -64.42 & -148.6 & -153.6 \\
\hline Wald Chi-2 test for zero coefficients (pval) & 0.0308 & 0.00242 & 0 & 0 \\
\hline Number of banks & 196 & 209 & 184 & 195 \\
\hline Number of failures & 12 & 14 & 40 & 41 \\
\hline Number of banks receiving RFC assistance & 84 & 92 & 50 & 54 \\
\hline
\end{tabular}


Table 7: First stage probit of Wooldridge's three-stage method (Dep Var $=$ RFC assistance dummy)

\begin{tabular}{|c|c|c|c|c|}
\hline VARIABLES & $\begin{array}{c}\text { Jan32 - Feb33 } \\
\text { Full } \\
\end{array}$ & $\begin{array}{l}\text { Jan32 - Feb33 } \\
\text { Parsimonious }\end{array}$ & $\begin{array}{c}\text { Mar33 - Dec34 } \\
\text { Full } \\
\end{array}$ & $\begin{array}{c}\text { Mar33 - Dec34 } \\
\text { Parsimonious }\end{array}$ \\
\hline Log of total assets & $\begin{array}{c}0.1214 \\
(0.1452)\end{array}$ & $\begin{array}{c}0.1853 \\
(0.1237)\end{array}$ & $\begin{array}{c}-0.3498^{* *} \\
(0.1589)\end{array}$ & $\begin{array}{l}-0.0258 \\
(0.1259)\end{array}$ \\
\hline Illiquid assets to total assets & $\begin{array}{c}5.0248 * * \\
(2.0594)\end{array}$ & $\begin{array}{c}2.2480 \\
(1.5840)\end{array}$ & $\begin{array}{c}-4.0364 * * \\
(2.0251)\end{array}$ & $\begin{array}{l}-1.4151 \\
(1.5287)\end{array}$ \\
\hline Real estate owned to illiquid assets & $\begin{array}{c}3.1094 \\
(6.1446)\end{array}$ & $\begin{array}{c}6.7679 \\
(5.2754)\end{array}$ & $\begin{array}{c}-13.8917^{*} \\
(8.2310)\end{array}$ & $\begin{array}{l}-6.8961 \\
(5.9172)\end{array}$ \\
\hline Net worth over total assets & $\begin{array}{c}-6.6669 * * \\
(2.9848)\end{array}$ & $\begin{array}{l}-2.8000 \\
(2.6535)\end{array}$ & $\begin{array}{l}-3.5245 \\
(3.1756)\end{array}$ & $\begin{array}{l}-2.4622 \\
(2.6005)\end{array}$ \\
\hline Bills payable and rediscounts over total debt & $\begin{array}{c}9.9167 * * * \\
(2.1137)\end{array}$ & $\begin{array}{c}7.8627^{* * *} \\
(2.0443)\end{array}$ & $\begin{array}{l}-0.2560 \\
(2.3208)\end{array}$ & $\begin{array}{l}-0.2226 \\
(1.9650)\end{array}$ \\
\hline National bank dummy & $\begin{array}{c}0.2649 \\
(0.2813)\end{array}$ & $\begin{array}{c}0.1481 \\
(0.2288)\end{array}$ & $\begin{array}{c}0.0339 \\
(0.2897)\end{array}$ & $\begin{array}{c}0.0274 \\
(0.2254)\end{array}$ \\
\hline Demand deposits and due to banks over total debt & $\begin{array}{c}2.4312 * * \\
(0.9773)\end{array}$ & & $\begin{array}{l}-2.0909 * \\
(1.0985)\end{array}$ & \\
\hline Loans and discounts to illiquid assets & $\begin{array}{c}0.7499 \\
(0.9359)\end{array}$ & & $\begin{array}{c}0.1339 \\
(0.9748)\end{array}$ & \\
\hline Loans eligible for rediscount over total loans and discounts & $\begin{array}{l}-1.5581 \\
(1.1640)\end{array}$ & & $\begin{array}{c}-2.5742 * * \\
(1.1677)\end{array}$ & \\
\hline Interest cost over total debt & $\begin{array}{c}1.5598 \\
(2.3380)\end{array}$ & & $\begin{array}{l}-0.7270 \\
(3.0651)\end{array}$ & \\
\hline Interest and discounts on loans over total earnings & $\begin{array}{l}-0.3372 \\
(0.6529)\end{array}$ & & $\begin{array}{l}1.5375 * * \\
(0.6849)\end{array}$ & \\
\hline Recoveries over total earnings & $\begin{array}{l}-2.8766 \\
(1.9965)\end{array}$ & & $\begin{array}{l}-1.1462 \\
(2.5652)\end{array}$ & \\
\hline Losses over total expenses & $\begin{array}{l}-0.1352 \\
(0.5897)\end{array}$ & & $\begin{array}{l}-0.5807 \\
(0.6021)\end{array}$ & \\
\hline Crop income share in county in 1930 & $\begin{array}{l}-2.6746 \\
(2.7195)\end{array}$ & & $\begin{array}{l}-5.1292 * \\
(2.7212)\end{array}$ & \\
\hline Total number of correspondents & $\begin{array}{l}-0.0970^{*} \\
(0.0560)\end{array}$ & $\begin{array}{c}-0.1122 * * \\
(0.0537)\end{array}$ & $\begin{array}{l}-0.1041^{*} \\
(0.0539)\end{array}$ & $\begin{array}{c}-0.0971 * * \\
(0.0484)\end{array}$ \\
\hline Number of correspondents in New York and Chicago & $\begin{array}{c}0.1172 \\
(0.1706)\end{array}$ & $\begin{array}{c}0.2235 \\
(0.1612)\end{array}$ & $\begin{array}{c}0.3907^{* *} \\
(0.1761)\end{array}$ & $\begin{array}{l}0.2898^{*} \\
(0.1625)\end{array}$ \\
\hline Log of county population in 1930 & $\begin{array}{c}0.0079 \\
(0.2084)\end{array}$ & $\begin{array}{l}0.2449 * \\
(0.1342)\end{array}$ & $\begin{array}{c}-0.6720 * * * \\
(0.2317)\end{array}$ & $\begin{array}{c}-0.0683 \\
(0.1296)\end{array}$ \\
\hline Unemployment rate for county in 1930 & $\begin{array}{c}-9.8401 * * \\
(4.8512)\end{array}$ & $\begin{array}{l}-6.0360 \\
(3.8857)\end{array}$ & $\begin{array}{l}-9.2573 * \\
(5.4336)\end{array}$ & $\begin{array}{c}0.1244 \\
(3.6460)\end{array}$ \\
\hline Net due to banks over total assets & $\begin{array}{c}3.7682 \\
(4.1035)\end{array}$ & $\begin{array}{c}2.6101 \\
(3.8267)\end{array}$ & $\begin{array}{c}1.9270 \\
(4.3278)\end{array}$ & $\begin{array}{l}-0.3335 \\
(3.5986)\end{array}$ \\
\hline Mortgage loan share of total loans for county & $\begin{array}{l}-1.3936 \\
(1.1253)\end{array}$ & & $\begin{array}{l}-1.6390 \\
(1.1417)\end{array}$ & \\
\hline Suspended deposits share of 1931 county deposits & $\begin{array}{c}0.0238 \\
(0.2827)\end{array}$ & & $\begin{array}{c}0.0443 \\
(0.3013)\end{array}$ & \\
\hline Other reserve city bank & $\begin{array}{l}-0.3355 \\
(0.7963)\end{array}$ & & $\begin{array}{l}1.0449 * \\
(0.6312)\end{array}$ & \\
\hline FERA share of grants for county & $\begin{array}{c}1.9529 \\
(2.3356)\end{array}$ & & $\begin{array}{c}1.7989 \\
(2.5577)\end{array}$ & \\
\hline Manufacturing employment share in county in 1930 & $\begin{array}{c}0.6886 \\
(1.1190)\end{array}$ & & $\begin{array}{c}5.3416^{* * *} \\
(1.4517)\end{array}$ & \\
\hline Constant & $\begin{array}{l}-2.7372 \\
(4.6761)\end{array}$ & $\begin{array}{c}-6.9657^{* * *} \\
(2.3450)\end{array}$ & $\begin{array}{c}20.4351^{* * *} \\
(5.5362)\end{array}$ & $\begin{array}{c}1.8572 \\
(2.4689)\end{array}$ \\
\hline
\end{tabular}


Table 8: Final stage, Wooldridge's three-stage method. Dep Var = Failure dummy.

\begin{tabular}{|c|c|c|c|c|}
\hline VARIABLES & $\begin{array}{c}\text { Jan32 - Feb33 } \\
\text { Full }\end{array}$ & $\begin{array}{l}\text { Jan32 - Feb33 } \\
\text { Parsimonious }\end{array}$ & $\begin{array}{c}\text { Mar33 - Dec34 } \\
\text { Full } \\
\end{array}$ & $\begin{array}{c}\text { Mar33 - Dec34 } \\
\text { Parsimonious }\end{array}$ \\
\hline Predicted probability of RFC assistance & $\begin{array}{l}-0.0641 \\
(0.1251)\end{array}$ & $\begin{array}{l}-0.0284 \\
(0.1265)\end{array}$ & $\begin{array}{c}-0.3839 * * \\
(0.1647)\end{array}$ & $\begin{array}{l}-0.8505^{*} \\
(0.4354)\end{array}$ \\
\hline Log of total assets & $\begin{array}{l}-0.0062 \\
(0.0162)\end{array}$ & $\begin{array}{l}-0.0098 \\
(0.0166)\end{array}$ & $\begin{array}{l}-0.0123 \\
(0.0282)\end{array}$ & $\begin{array}{c}0.0266 \\
(0.0249)\end{array}$ \\
\hline Illiquid assets over total assets & $\begin{array}{c}0.4048 \\
(0.3123)\end{array}$ & $\begin{array}{c}0.4846 * * \\
(0.2407)\end{array}$ & $\begin{array}{c}0.2199 \\
(0.4231)\end{array}$ & $\begin{array}{l}-0.1977 \\
(0.4893)\end{array}$ \\
\hline Real estate owned over illiquid assets & $\begin{array}{c}1.0067 \\
(0.9037)\end{array}$ & $\begin{array}{c}0.8291 \\
(0.9621)\end{array}$ & $\begin{array}{c}2.0055 \\
(1.7150)\end{array}$ & $\begin{array}{c}2.3518 \\
(1.8571)\end{array}$ \\
\hline Net worth over total assets & $\begin{array}{l}-0.0828 \\
(0.3225)\end{array}$ & $\begin{array}{l}-0.0729 \\
(0.3684)\end{array}$ & $\begin{array}{c}-1.5793 * * \\
(0.7423)\end{array}$ & $\begin{array}{l}-1.6869 * \\
(0.8902)\end{array}$ \\
\hline Bills payable and rediscounts over total debt & $\begin{array}{c}0.7647 \\
(0.5927)\end{array}$ & $\begin{array}{l}1.1316^{*} \\
(0.6019)\end{array}$ & $\begin{array}{c}1.3659 * * \\
(0.5584)\end{array}$ & $\begin{array}{c}1.4183^{* *} \\
(0.7052)\end{array}$ \\
\hline National bank dummy & $\begin{array}{c}0.0198 \\
(0.0417)\end{array}$ & $\begin{array}{l}-0.0018 \\
(0.0349)\end{array}$ & $\begin{array}{c}0.3552^{* * *} \\
(0.0716)\end{array}$ & $\begin{array}{c}0.3411^{* * *} \\
(0.0745)\end{array}$ \\
\hline Demand deposits and due to banks over total debt & $\begin{array}{l}-0.1392 \\
(0.1422)\end{array}$ & & $\begin{array}{c}0.1818 \\
(0.2197)\end{array}$ & \\
\hline Loans and discounts over illiquid assets & $\begin{array}{c}0.1202 \\
(0.0908)\end{array}$ & & $\begin{array}{c}0.1525 \\
(0.1791)\end{array}$ & \\
\hline Loans eligible for rediscount over total loans and discounts & $\begin{array}{l}-0.1449 \\
(0.1797)\end{array}$ & & $\begin{array}{l}-0.4243 \\
(0.2770)\end{array}$ & \\
\hline Interest cost over total debt & $\begin{array}{c}0.4372 \\
(0.7491)\end{array}$ & & $\begin{array}{l}-0.1950 \\
(0.4070)\end{array}$ & \\
\hline Interest and discounts on loans over total earnings & $\begin{array}{c}0.0199 \\
(0.0942)\end{array}$ & & $\begin{array}{c}0.2084 \\
(0.1719)\end{array}$ & \\
\hline Recoveries over total earnings & $\begin{array}{l}-0.1363 \\
(0.2293)\end{array}$ & & $\begin{array}{c}-1.0993 * * * \\
(0.4262)\end{array}$ & \\
\hline Losses over total expenses & $\begin{array}{c}-0.0931^{*} \\
(0.0540)\end{array}$ & & $\begin{array}{c}0.0695 \\
(0.1471)\end{array}$ & \\
\hline Crop income share in county in 1930 & $\begin{array}{c}0.0485 \\
(0.1527)\end{array}$ & & $\begin{array}{l}-0.4327 \\
(0.4723)\end{array}$ & \\
\hline Constant & $\begin{array}{l}-0.2632 \\
(0.3900)\end{array}$ & $\begin{array}{l}-0.2374 \\
(0.3447)\end{array}$ & $\begin{array}{c}0.4885 \\
(0.8623)\end{array}$ & $\begin{array}{c}0.1755 \\
(0.7642)\end{array}$ \\
\hline Number of banks & 195 & 208 & 183 & 194 \\
\hline Number of failures & 12 & 14 & 38 & 39 \\
\hline Number of banks receiving RFC assistance & 84 & 92 & 50 & 54 \\
\hline Centered R2 & 0.124 & 0.120 & 0.274 & 0.0868 \\
\hline Adjusted R2 & 0.0506 & 0.0467 & 0.209 & 0.00472 \\
\hline Anderson-Rubin Wald (significance of endog, chi-sq stat) & 0.269 & 0.00648 & 5.579 & 4.051 \\
\hline Anderson-Rubin Wald (significance of endog, pval) & 0.604 & 0.936 & 0.0182 & 0.0441 \\
\hline Kleibergen-Paap rk LM (underid, pval) & 0.000811 & 0.00852 & $8.92 \mathrm{e}-06$ & 0.0156 \\
\hline Kleibergen-Paap rk Wald F (weakid, stat) & 13.89 & 7.539 & 25.24 & 6.368 \\
\hline Cragg-Donald Wald F (weakid, stat) & 13.00 & 7.678 & 26.75 & 5.968 \\
\hline Stock-Yogo weakid $10 \%$ critical values (maxIV) & 16.38 & 16.38 & 16.38 & 16.38 \\
\hline Endogeneity test (Chi-sq(1) stat) & 0.0651 & 0.110 & 1.542 & 2.137 \\
\hline Endogeneity test ( $p$-val) & 0.799 & 0.740 & 0.214 & 0.144 \\
\hline
\end{tabular}


Table 9: First stage, bivariate tobit log-duration. Dep Var $=\log$ (Days to RFC assist)

\begin{tabular}{|c|c|c|c|}
\hline VARIABLES & $\begin{array}{c}\text { Jan32 - Feb33 } \\
\text { Full }\end{array}$ & $\begin{array}{l}\text { Jan32 - Feb33 } \\
\text { Parsimonious }\end{array}$ & $\begin{array}{c}\text { Mar33 - Dec36 } \\
\text { Full } \\
\end{array}$ \\
\hline Log of total assets & $\begin{array}{l}-0.0500 \\
(0.0816)\end{array}$ & $\begin{array}{c}-0.1008^{* *} \\
(0.0402)\end{array}$ & $\begin{array}{c}0.0542 \\
(0.0736)\end{array}$ \\
\hline Illiquid assets to total assets & $\begin{array}{l}-0.9747^{*} \\
(0.5901)\end{array}$ & $\begin{array}{l}-0.8839 \\
(0.6243)\end{array}$ & $\begin{array}{c}1.0055 \\
(0.8097)\end{array}$ \\
\hline Real estate owned to illiquid assets & $\begin{array}{l}-1.3821 \\
(1.9465)\end{array}$ & $\begin{array}{l}-2.4902 \\
(1.8189)\end{array}$ & $\begin{array}{c}1.1328 \\
(2.7292)\end{array}$ \\
\hline Net worth over total assets & $\begin{array}{c}1.2482 \\
(1.0550)\end{array}$ & $\begin{array}{l}-0.2963 \\
(0.9991)\end{array}$ & $\begin{array}{c}1.3265 \\
(1.2341)\end{array}$ \\
\hline Bills payable and rediscounts over total debt & $\begin{array}{c}-3.1648 * * * \\
(0.6368)\end{array}$ & $\begin{array}{c}-2.7218 * * * \\
(0.6692)\end{array}$ & $\begin{array}{c}1.1760 \\
(0.9218)\end{array}$ \\
\hline National bank dummy & $\begin{array}{c}0.0083 \\
(0.1098)\end{array}$ & $\begin{array}{l}-0.0367 \\
(0.0832)\end{array}$ & $\begin{array}{l}-0.1885^{*} \\
(0.1125)\end{array}$ \\
\hline Demand deposits and due to banks over total debt & $\begin{array}{l}-0.4518 \\
(0.3226)\end{array}$ & & $\begin{array}{c}0.4587 \\
(0.4347)\end{array}$ \\
\hline Loans and discounts to illiquid assets & $\begin{array}{l}-0.2839 \\
(0.2820)\end{array}$ & & $\begin{array}{l}-0.3394 \\
(0.3580)\end{array}$ \\
\hline Loans eligible for rediscount over total loans and discounts & $\begin{array}{c}0.2190 \\
(0.3407)\end{array}$ & & $\begin{array}{l}0.8620 * \\
(0.4557)\end{array}$ \\
\hline Interest cost over total debt & $\begin{array}{c}0.2861 \\
(0.9005)\end{array}$ & & $\begin{array}{l}-0.2131 \\
(1.2206)\end{array}$ \\
\hline Interest and discounts on loans over total earnings & $\begin{array}{c}0.2911 \\
(0.1946)\end{array}$ & & $\begin{array}{l}-0.3795 \\
(0.2829)\end{array}$ \\
\hline Recoveries over total earnings & $\begin{array}{c}0.3989 \\
(0.7831)\end{array}$ & & $\begin{array}{c}0.3592 \\
(1.0011)\end{array}$ \\
\hline Losses over total expenses & $\begin{array}{l}-0.1116 \\
(0.2076)\end{array}$ & & $\begin{array}{c}0.2826 \\
(0.2951)\end{array}$ \\
\hline Crop income share in county in 1930 & $\begin{array}{l}-1.3804^{*} \\
(0.7875)\end{array}$ & & $\begin{array}{c}1.9292 \\
(1.1924)\end{array}$ \\
\hline Total number of correspondents & $\begin{array}{c}0.0116 \\
(0.0190)\end{array}$ & $\begin{array}{c}0.0275 \\
(0.0175)\end{array}$ & $\begin{array}{c}0.0712 * * * \\
(0.0184)\end{array}$ \\
\hline Number of correspondents in New York and Chicago & $\begin{array}{l}-0.0253 \\
(0.0757)\end{array}$ & $\begin{array}{l}-0.0425 \\
(0.0561)\end{array}$ & $\begin{array}{c}-0.1493^{* *} \\
(0.0619)\end{array}$ \\
\hline Log of county population in 1930 & $\begin{array}{l}-0.0834 \\
(0.0735)\end{array}$ & $\begin{array}{l}-0.0591 \\
(0.0449)\end{array}$ & $\begin{array}{c}0.1899 * * \\
(0.0827)\end{array}$ \\
\hline Unemployment rate for county in 1930 & $\begin{array}{c}4.2360 * * * \\
(1.5645)\end{array}$ & $\begin{array}{c}3.2350 * * \\
(1.2676)\end{array}$ & $\begin{array}{c}2.5718 \\
(1.9048)\end{array}$ \\
\hline Net due to banks over total assets & $\begin{array}{l}-1.1723 \\
(1.2172)\end{array}$ & $\begin{array}{l}-0.3009 \\
(1.3230)\end{array}$ & $\begin{array}{l}-0.7251 \\
(1.4082)\end{array}$ \\
\hline Mortgage loan share of total loans for county & $\begin{array}{c}0.1139 \\
(0.4153)\end{array}$ & & $\begin{array}{l}0.8096^{*} \\
(0.4324)\end{array}$ \\
\hline Suspended deposits share of 1931 county deposits & $\begin{array}{l}-0.0994 \\
(0.0752)\end{array}$ & & $\begin{array}{c}0.0436 \\
(0.1049)\end{array}$ \\
\hline Other reserve city bank & $\begin{array}{c}0.0869 \\
(0.2014)\end{array}$ & & $\begin{array}{l}-0.1503 \\
(0.2610)\end{array}$ \\
\hline FERA share of grants for county & $\begin{array}{l}-0.9169 \\
(0.9777)\end{array}$ & & $\begin{array}{l}-0.9156 \\
(0.7949)\end{array}$ \\
\hline Manufacturing employment share in county in 1930 & $\begin{array}{l}-0.3535 \\
(0.5169)\end{array}$ & & $\begin{array}{c}-1.2029 * * \\
(0.4892)\end{array}$ \\
\hline Constant & $\begin{array}{c}9.3434 * * * \\
(1.5416)\end{array}$ & $\begin{array}{c}8.3720 * * * \\
(0.8099)\end{array}$ & $\begin{array}{c}1.0890 \\
(2.6122)\end{array}$ \\
\hline In(sigma1) & $\begin{array}{c}-1.2246 * * * \\
(0.0665)\end{array}$ & $\begin{array}{c}-1.2346 * * * \\
(0.0503)\end{array}$ & $\begin{array}{c}-0.3970 * * \\
(0.1855)\end{array}$ \\
\hline
\end{tabular}

Robust standard errors in parentheses, ${ }^{* * *} p<0.01,{ }^{* *} p<0.05, * p<0.1$ 
Table 10: Second stage, bivariate tobit log-duration. Dep Var = log (Days to Failure)

\begin{tabular}{|c|c|c|c|}
\hline VARIABLES & $\begin{array}{c}\text { Jan32 - Feb33 } \\
\text { Full }\end{array}$ & $\begin{array}{l}\text { Jan32 - Feb33 } \\
\text { Parsimonious }\end{array}$ & $\begin{array}{c}\text { Mar33 - Dec36 } \\
\text { Full }\end{array}$ \\
\hline \multirow[t]{2}{*}{ Log of days to RFC assistance } & 0.0800 & -0.0807 & $-0.8950 * * *$ \\
\hline & $(0.0737)$ & $(0.0875)$ & $(0.2888)$ \\
\hline \multirow[t]{2}{*}{ Log of total assets } & 0.0096 & 0.0080 & -0.0358 \\
\hline & $(0.0230)$ & $(0.0183)$ & $(0.0493)$ \\
\hline \multirow[t]{2}{*}{ Illiquid assets to total assets } & -0.0011 & -0.4480 & -0.3785 \\
\hline & $(0.3392)$ & $(0.3343)$ & $(0.9100)$ \\
\hline \multirow[t]{2}{*}{ Real estate owned to illiquid assets } & $-1.7933 *$ & -1.7262 & -2.9847 \\
\hline & $(1.0880)$ & $(1.1944)$ & $(3.2587)$ \\
\hline \multirow[t]{2}{*}{ Net worth over total assets } & 0.2335 & 0.3439 & $3.1802 * *$ \\
\hline & $(0.6217)$ & $(0.5679)$ & $(1.3950)$ \\
\hline \multirow[t]{2}{*}{ Bills payable and rediscounts over total debt } & -0.2807 & $-1.2484 * *$ & -1.0120 \\
\hline & $(0.4170)$ & $(0.5470)$ & $(1.0431)$ \\
\hline \multirow[t]{2}{*}{ National bank dummy } & 0.0334 & 0.0337 & $-0.7572 * * *$ \\
\hline & $(0.0568)$ & $(0.0487)$ & $(0.1347)$ \\
\hline \multirow[t]{2}{*}{ Demand deposits and due to banks over total debt } & 0.3302 & & -0.3927 \\
\hline & $(0.2045)$ & & $(0.5654)$ \\
\hline \multirow[t]{2}{*}{ Loans and discounts to illiquid assets } & 0.0247 & & -0.2104 \\
\hline & $(0.1672)$ & & $(0.3881)$ \\
\hline \multirow[t]{2}{*}{ Loans eligible for rediscount over total loans and discounts } & 0.0613 & & 0.8871 \\
\hline & $(0.1938)$ & & $(0.6026)$ \\
\hline \multirow[t]{2}{*}{ Interest cost over total debt } & -0.3393 & & -0.0755 \\
\hline & $(0.4291)$ & & $(1.4002)$ \\
\hline \multirow[t]{2}{*}{ Interest and discounts on loans over total earnings } & -0.1474 & & -0.4245 \\
\hline & $(0.1122)$ & & $(0.3506)$ \\
\hline \multirow[t]{2}{*}{ Recoveries over total earnings } & -0.1609 & & 1.7217 \\
\hline & $(0.4687)$ & & $(1.1400)$ \\
\hline \multirow[t]{2}{*}{ Losses over total expenses } & 0.0639 & & 0.0459 \\
\hline & $(0.1489)$ & & $(0.3669)$ \\
\hline \multirow[t]{2}{*}{ Crop income share in county in 1930} & -0.0436 & & 1.4281 \\
\hline & $(0.3304)$ & & $(0.9689)$ \\
\hline \multirow[t]{2}{*}{ Constant } & $5.4175^{* * *}$ & $6.7230 * * *$ & $12.8397 * * *$ \\
\hline & $(0.9137)$ & $(0.8367)$ & $(2.6606)$ \\
\hline \multirow[t]{2}{*}{ Ln(Sigma2) } & $-0.7934 * * *$ & $-0.7413 * * *$ & $-0.5405 * * *$ \\
\hline & $(0.0654)$ & $(0.0518)$ & $(0.0756)$ \\
\hline \multirow[t]{2}{*}{$\operatorname{atan}(\mathrm{Rho12})$} & $-0.2759 *$ & -0.0019 & $0.7410^{* *}$ \\
\hline & $(0.1623)$ & $(0.1530)$ & $(0.3095)$ \\
\hline Rho12 & -0.2831 & -0.0019 & 0.9149 \\
\hline Log pseudolikelihood & -152.5 & -179.3 & -301.6 \\
\hline Number of banks & 195 & 208 & 183 \\
\hline Number of failures & 12 & 14 & 40 \\
\hline Number of banks receiving RFC assistance & 84 & 92 & 50 \\
\hline
\end{tabular}

Robust standard errors in parentheses, *** $\mathrm{p}<0.01,{ }^{* *} \mathrm{p}<0.05, * \mathrm{p}<0.1$ 
Table 11: Loan Growth: Wooldridge Three Stage Method: First stage, Probit, only survivors through 1935. Dep Var = RFC assistance dummy.

\begin{tabular}{|c|c|c|}
\hline VARIABLES & Full & Parsimonious \\
\hline \multirow[t]{2}{*}{ Log of total assets } & -0.1035 & -0.0732 \\
\hline & $(0.2259)$ & $(0.1683)$ \\
\hline \multirow[t]{2}{*}{ Illiquid assets over total assets } & -2.2207 & -0.8848 \\
\hline & $(2.8459)$ & $(1.8963)$ \\
\hline \multirow[t]{2}{*}{ Real estate owned over illiquid assets } & $-17.7440^{*}$ & -4.4528 \\
\hline & $(9.3484)$ & (7.8164) \\
\hline \multirow{2}{*}{ Net worth over total assets } & -6.0015 & $-6.1776 *$ \\
\hline & $(4.9315)$ & $(3.3091)$ \\
\hline \multirow[t]{2}{*}{ Bills payable and rediscounts over total debt } & $6.1027^{*}$ & 2.9050 \\
\hline & $(3.1813)$ & $(2.8658)$ \\
\hline \multirow[t]{2}{*}{ National bank dummy } & 0.1039 & 0.1738 \\
\hline & $(0.4921)$ & $(0.2944)$ \\
\hline \multirow[t]{2}{*}{ Demand deposits and due to banks over total debt } & -2.0545 & \\
\hline & $(1.8333)$ & \\
\hline \multirow[t]{2}{*}{ Loans and discounts over illiquid assets } & -0.8944 & \\
\hline & $(1.3014)$ & \\
\hline \multirow[t]{2}{*}{ Loans eligible for rediscount over total loans and discounts } & -2.0087 & \\
\hline & $(1.6241)$ & \\
\hline \multirow[t]{2}{*}{ Interest cost over total debt } & -4.2569 & \\
\hline & $(5.1089)$ & \\
\hline \multirow[t]{2}{*}{ Interest and discounts on loans over total earnings } & $3.6247^{* * *}$ & \\
\hline & $(0.9803)$ & \\
\hline \multirow[t]{2}{*}{ Recoveries over total earnings } & -3.5602 & \\
\hline & $(3.9870)$ & \\
\hline \multirow[t]{2}{*}{ Losses over total expenses } & 0.8915 & \\
\hline & $(1.0344)$ & \\
\hline \multirow[t]{2}{*}{ Crop income share in county in 1930} & $131.9727^{* * *}$ & \\
\hline & $(37.8384)$ & \\
\hline \multirow[t]{2}{*}{ Total number of correspondents } & 0.1329 & 0.1394 \\
\hline & (0.1929) & $(0.1344)$ \\
\hline \multirow{2}{*}{ Number of correspondents in New York and Chicago } & -0.1505 & 0.0565 \\
\hline & $(0.2821)$ & $(0.2176)$ \\
\hline \multirow[t]{2}{*}{ Log of county population in 1930} & -0.4904 & 0.0605 \\
\hline & $(0.3412)$ & $(0.1685)$ \\
\hline \multirow{2}{*}{ Unemployment rate for county in 1930} & 0.4107 & 5.9868 \\
\hline & $(7.5312)$ & $(5.1588)$ \\
\hline \multirow[t]{2}{*}{ Net due to banks over total assets } & -0.3268 & 0.1811 \\
\hline & $(6.0087)$ & $(4.6216)$ \\
\hline \multirow[t]{2}{*}{ Mortgage loan share of total loans for county } & -0.7401 & \\
\hline & $(1.4757)$ & \\
\hline Suspended deposits share of 1931 county deposits & -0.0656 & \\
\hline & $(0.3273)$ & \\
\hline FERA share of grants for county & $12.6545^{* * *}$ & \\
\hline & $(4.0870)$ & \\
\hline Manufacturing employment share in county in 1930 & $10.0360 * * *$ & \\
\hline & $(2.7121)$ & \\
\hline Constant & $-126.7968 * * *$ & 0.4709 \\
\hline & $(39.8363)$ & (3.0385) \\
\hline Pseudo R2 & 0.324 & 0.0768 \\
\hline Log-likelihood & -45.79 & -70.64 \\
\hline Log-likelihood constant only & -67.70 & -76.51 \\
\hline LR Chi-2 test for zero coefficients (pval) & 0.00468 & 0.496 \\
\hline Number of banks & 104 & 115 \\
\hline Number of banks receiving RFC stock assistance & 37 & 44 \\
\hline
\end{tabular}


Table 12: Loan Growth: Wooldridge Three Stage Method: Second and Third stage, 2SLS. Dep Var = loan growth.

\begin{tabular}{|c|c|c|}
\hline VARIABLES & Full & Parsimonious \\
\hline \multirow[t]{2}{*}{ RFC assistance dummy } & $0.3901^{*}$ & 0.5070 \\
\hline & $(0.2102)$ & $(0.3884)$ \\
\hline \multirow[t]{2}{*}{ Log of total assets } & -0.0199 & -0.0645 \\
\hline & $(0.0632)$ & $(0.0516)$ \\
\hline \multirow[t]{2}{*}{ Illiquid assets over total assets } & $-2.6490 * * *$ & $-2.5036 * * *$ \\
\hline & $(0.6820)$ & $(0.6738)$ \\
\hline \multirow[t]{2}{*}{ Real estate owned over illiquid assets } & -3.6461 & -3.6492 \\
\hline & $(3.7875)$ & $(3.6041)$ \\
\hline \multirow[t]{2}{*}{ Net worth over total assets } & 2.0565 & 1.8447 \\
\hline & $(1.3972)$ & $(1.4288)$ \\
\hline \multirow[t]{2}{*}{ Bills payable and rediscounts over total debt } & -0.3307 & -0.2266 \\
\hline & $(0.8516)$ & $(0.8759)$ \\
\hline \multirow[t]{2}{*}{ National bank dummy } & -0.1607 & -0.1471 \\
\hline & $(0.1242)$ & $(0.0957)$ \\
\hline \multirow[t]{2}{*}{ Demand deposits and due to banks over total debt } & -0.1247 & \\
\hline & $(0.4524)$ & \\
\hline \multirow[t]{2}{*}{ Loans and discounts over illiquid assets } & -0.0370 & \\
\hline & $(0.3950)$ & \\
\hline \multirow[t]{2}{*}{ Loans eligible for rediscount over total loans and discounts } & 0.6683 & \\
\hline & $(0.5182)$ & \\
\hline \multirow[t]{2}{*}{ Interest cost over total debt } & 1.1584 & \\
\hline & $(0.9861)$ & \\
\hline \multirow[t]{2}{*}{ Interest and discounts on loans over total earnings } & -0.0292 & \\
\hline & $(0.3342)$ & \\
\hline \multirow[t]{2}{*}{ Recoveries over total earnings } & 0.5160 & \\
\hline & $(0.8242)$ & \\
\hline \multirow[t]{2}{*}{ Losses over total expenses } & 0.2659 & \\
\hline & $(0.3086)$ & \\
\hline \multirow[t]{2}{*}{ Crop income share in county in 1930} & -0.7087 & \\
\hline & $(0.6331)$ & \\
\hline \multirow[t]{2}{*}{ Constant } & $2.0532 *$ & $1.9687^{* *}$ \\
\hline & $(1.2167)$ & (0.9509) \\
\hline Centered R2 & 0.334 & 0.240 \\
\hline Adjusted R2 & 0.220 & 0.190 \\
\hline Anderson-Rubin Wald (significance of endogenous, chi-sq stat) & 3.264 & 2.002 \\
\hline Anderson-Rubin Wald (significance of endogenous, pval) & 0.0708 & 0.157 \\
\hline Kleibergen-Paap rk LM (underid, pval) & $9.30 \mathrm{e}-05$ & 0.0384 \\
\hline Kleibergen-Paap rk Wald F (weakid, stat) & 30.00 & 5.044 \\
\hline Cragg-Donald Wald F (weakid, stat) & 22.46 & 4.298 \\
\hline Stock-Yogo weakid $10 \%$ critical values (maxIV) & 16.38 & 16.38 \\
\hline Endogeneity test (Chi-sq(1) stat) & 0.528 & 0.693 \\
\hline Endogeneity test ( $p$-val) & 0.468 & 0.405 \\
\hline Number of banks & 104 & 115 \\
\hline Number of banks receiving RFC stock assistance & 37 & 44 \\
\hline
\end{tabular}

Robust standard errors in parentheses

$* * * p<0.01,{ }^{* *} p<0.05, * p<0.1$ 
Table 13: 1st stage, Joint MLE, includes survivors through 1935.

\begin{tabular}{|c|c|c|c|}
\hline VARIABLES & $\begin{array}{c}\text { Parsimonious } \\
\text { First stage Probit }\end{array}$ & $\begin{array}{c}\text { Full } \\
\text { First stage Tobit }\end{array}$ & $\begin{array}{c}\text { Parsimonious } \\
\text { First stage Tobit }\end{array}$ \\
\hline (Dependent Variable) & RFC assistance dummy & $\begin{array}{l}\text { Log of days to RFC } \\
\text { assistance }\end{array}$ & $\begin{array}{l}\text { Log of days to RFC } \\
\text { assistance }\end{array}$ \\
\hline \multirow[t]{2}{*}{ Log of total assets } & -0.0877 & 0.1267 & 0.0298 \\
\hline & $(0.1590)$ & $(0.0777)$ & $(0.0760)$ \\
\hline \multirow[t]{2}{*}{ Illiquid assets to total assets } & -1.0623 & 1.1917 & 0.4250 \\
\hline & $(1.9471)$ & $(0.9971)$ & $(0.8898)$ \\
\hline \multirow[t]{2}{*}{ Real estate owned to illiquid assets } & -3.7115 & 4.6104 & 1.1739 \\
\hline & $(7.4956)$ & $(4.3834)$ & $(3.2923)$ \\
\hline \multirow[t]{2}{*}{ Net worth over total assets } & $-6.3850 *$ & $4.3579 * * *$ & $3.4066^{* *}$ \\
\hline & $(3.2923)$ & $(1.5592)$ & $(1.4344)$ \\
\hline \multirow[t]{2}{*}{ Bills payable and rediscounts over total debt } & 3.8176 & -0.9318 & -0.4100 \\
\hline & $(2.6244)$ & $(1.2749)$ & $(1.2594)$ \\
\hline \multirow[t]{2}{*}{ National bank dummy } & 0.1992 & -0.0502 & -0.1725 \\
\hline & $(0.3092)$ & $(0.1713)$ & $(0.1332)$ \\
\hline \multirow[t]{2}{*}{ Demand deposits and due to banks over total debt } & & -0.1536 & \\
\hline & & $(0.5926)$ & \\
\hline \multirow[t]{2}{*}{ Loans and discounts to illiquid assets } & & 0.0193 & \\
\hline & & $(0.4924)$ & \\
\hline \multirow[t]{2}{*}{ Loans eligible for rediscount over total loans and discounts } & & 1.0365 & \\
\hline & & $(0.6670)$ & \\
\hline \multirow[t]{2}{*}{ Interest cost over total debt } & & 0.4885 & \\
\hline & & $(1.6955)$ & \\
\hline \multirow[t]{2}{*}{ Interest and discounts on loans over total earnings } & & $-0.6798 *$ & \\
\hline & & $(0.3526)$ & \\
\hline \multirow[t]{2}{*}{ Recoveries over total earnings } & & 0.8347 & \\
\hline & & $(1.2314)$ & \\
\hline \multirow[t]{2}{*}{ Losses over total expenses } & & -0.1514 & \\
\hline & & $(0.3792)$ & \\
\hline \multirow[t]{2}{*}{ Crop income share in county in 1930} & & 0.9503 & \\
\hline & & $(1.7985)$ & \\
\hline \multirow{2}{*}{ Total number of correspondents } & 0.0952 & -0.0142 & -0.0554 \\
\hline & $(0.1102)$ & $(0.0727)$ & $(0.0548)$ \\
\hline \multirow[t]{2}{*}{ Number of correspondents in New York and Chicago } & 0.0991 & -0.0645 & -0.0850 \\
\hline & $(0.1572)$ & $(0.0916)$ & $(0.0849)$ \\
\hline \multirow[t]{2}{*}{ Log of county population in 1930} & 0.0882 & $0.2096^{*}$ & -0.0764 \\
\hline & $(0.1243)$ & $(0.1182)$ & $(0.0635)$ \\
\hline \multirow[t]{2}{*}{ Unemployment rate for county in 1930} & 2.2911 & 3.2016 & -0.0036 \\
\hline & $(3.9787)$ & $(2.7596)$ & $(1.9470)$ \\
\hline \multirow[t]{2}{*}{ Net due to banks over total assets } & -2.0226 & -1.2168 & -0.4915 \\
\hline & (3.7949) & $(2.1251)$ & $(1.9687)$ \\
\hline \multirow[t]{2}{*}{ Mortgage loan share of total loans for county } & & 0.4124 & \\
\hline & & $(0.5549)$ & \\
\hline Suspended deposits share of 1931 county deposits & & 0.0751 & \\
\hline & & $(0.1513)$ & \\
\hline Other reserve city bank & & $-1.1674 * *$ & \\
\hline & & $(0.5196)$ & \\
\hline FERA share of grants for county & & $-2.8142^{*}$ & \\
\hline & & $(1.5192)$ & \\
\hline Manufacturing employment share in county in 1930 & & $-1.4805^{* *}$ & \\
\hline & & $(0.6262)$ & \\
\hline Constant & 0.7612 & 0.9374 & $6.7588 * * *$ \\
\hline & $(2.7992)$ & $(3.0416)$ & $(1.3941)$ \\
\hline Insig_1 & $-0.5975 * * *$ & $-0.7824 * * *$ & $-0.6501 * * *$ \\
\hline & $(0.1372)$ & $(0.1082)$ & (0.1395) \\
\hline
\end{tabular}

Robust standard errors in parentheses, ${ }^{* * *} p<0.01,{ }^{* *} p<0.05,{ }^{*} p<0.1$ 
Table 14: 2nd stage (Loan Growth), Joint MLE, includes survivors through 1935.

\begin{tabular}{|c|c|c|c|}
\hline VARIABLES & $\begin{array}{c}\text { Parsimonious Probit-OLS } \\
\text { Second stage OLS }\end{array}$ & $\begin{array}{c}\text { Full Tobit-OLS } \\
\text { Second stage OLS }\end{array}$ & $\begin{array}{c}\text { Parsimonious Tobit-OLS } \\
\text { Second stage OLS }\end{array}$ \\
\hline RFC assistance dummy & $\begin{array}{c}0.9337^{* * *} \\
(0.2308)\end{array}$ & & \\
\hline Log of days to RFC assistance & & $\begin{array}{l}-0.4078^{*} \\
(0.2132)\end{array}$ & $\begin{array}{c}-0.5887 * * * \\
(0.1495)\end{array}$ \\
\hline Log of total assets & $\begin{array}{l}-0.0871^{*} \\
(0.0502)\end{array}$ & $\begin{array}{l}-0.0270 \\
(0.0517)\end{array}$ & $\begin{array}{c}-0.0955^{* *} \\
(0.0427)\end{array}$ \\
\hline Illiquid assets to total assets & $\begin{array}{c}-2.3149 * * * \\
(0.7483)\end{array}$ & $\begin{array}{l}-2.6528 * * * \\
(0.6865)\end{array}$ & $\begin{array}{c}-2.5224 * * * \\
(0.6580)\end{array}$ \\
\hline Real estate owned to illiquid assets & $\begin{array}{l}-2.9507 \\
(3.3847)\end{array}$ & $\begin{array}{l}-2.9688 \\
(3.7077)\end{array}$ & $\begin{array}{l}-3.4973 \\
(2.8429)\end{array}$ \\
\hline Net worth over total assets & $\begin{array}{l}2.6204^{*} \\
(1.3535)\end{array}$ & $\begin{array}{l}2.5512 * \\
(1.3966)\end{array}$ & $\begin{array}{r}2.4702 * * \\
(1.2041)\end{array}$ \\
\hline Bills payable and rediscounts over total debt & $\begin{array}{l}-0.5529 \\
(1.1462)\end{array}$ & $\begin{array}{l}-0.0722 \\
(0.9742)\end{array}$ & $\begin{array}{c}0.1037 \\
(1.0701)\end{array}$ \\
\hline National bank dummy & $\begin{array}{l}-0.1783 \\
(0.1225)\end{array}$ & $\begin{array}{l}-0.2063 \\
(0.1354)\end{array}$ & $\begin{array}{c}-0.2259 * * \\
(0.1126)\end{array}$ \\
\hline Demand deposits and due to banks over total debt & & $\begin{array}{l}-0.1914 \\
(0.4569)\end{array}$ & \\
\hline Loans and discounts to illiquid assets & & $\begin{array}{l}-0.1004 \\
(0.3557)\end{array}$ & \\
\hline $\begin{array}{l}\text { Loans eligible for rediscount over total loans and } \\
\text { discounts }\end{array}$ & & $\begin{array}{c}0.8139 \\
(0.5314)\end{array}$ & \\
\hline Interest cost over total debt & & $\begin{array}{c}0.9337 \\
(1.2824)\end{array}$ & \\
\hline Interest and discounts on loans over total earnings & & $\begin{array}{l}-0.0778 \\
(0.3150)\end{array}$ & \\
\hline Recoveries over total earnings & & $\begin{array}{c}0.7104 \\
(0.9920)\end{array}$ & \\
\hline Losses over total expenses & & $\begin{array}{c}0.2247 \\
(0.3055)\end{array}$ & \\
\hline Crop income share in county in 1930 & & $\begin{array}{l}-0.1645 \\
(0.9557)\end{array}$ & \\
\hline Constant & $\begin{array}{l}1.8812^{*} \\
(1.0621)\end{array}$ & $\begin{array}{c}4.5331^{* *} \\
(1.7877)\end{array}$ & $\begin{array}{c}6.5298 * * * \\
(1.4134)\end{array}$ \\
\hline In (sigma2) & $\begin{array}{c}-0.5975 * * * \\
(0.1372) \\
\end{array}$ & $\begin{array}{c}-0.5900 * * * \\
(0.0707)\end{array}$ & $\begin{array}{c}-0.4636 * * * \\
(0.0779)\end{array}$ \\
\hline Rho_12 & $-0.8113 * * *$ & 0.3641 & $0.7221 * * *$ \\
\hline Log-likelihood & -136.9 & -150.4 & -177.1 \\
\hline Number of banks & 115 & 107 & 115 \\
\hline Number of banks with RFC stock assistance & 44 & 40 & 44 \\
\hline
\end{tabular}

Robust standard errors in parentheses, ${ }^{* * *} \mathrm{p}<0.01,{ }^{* *} \mathrm{p}<0.05,{ }^{*} \mathrm{p}<0.1$ 
Figure 1: Bank failures and RFC loan and preferred stock assistance recipients, January 1932 - December 1934

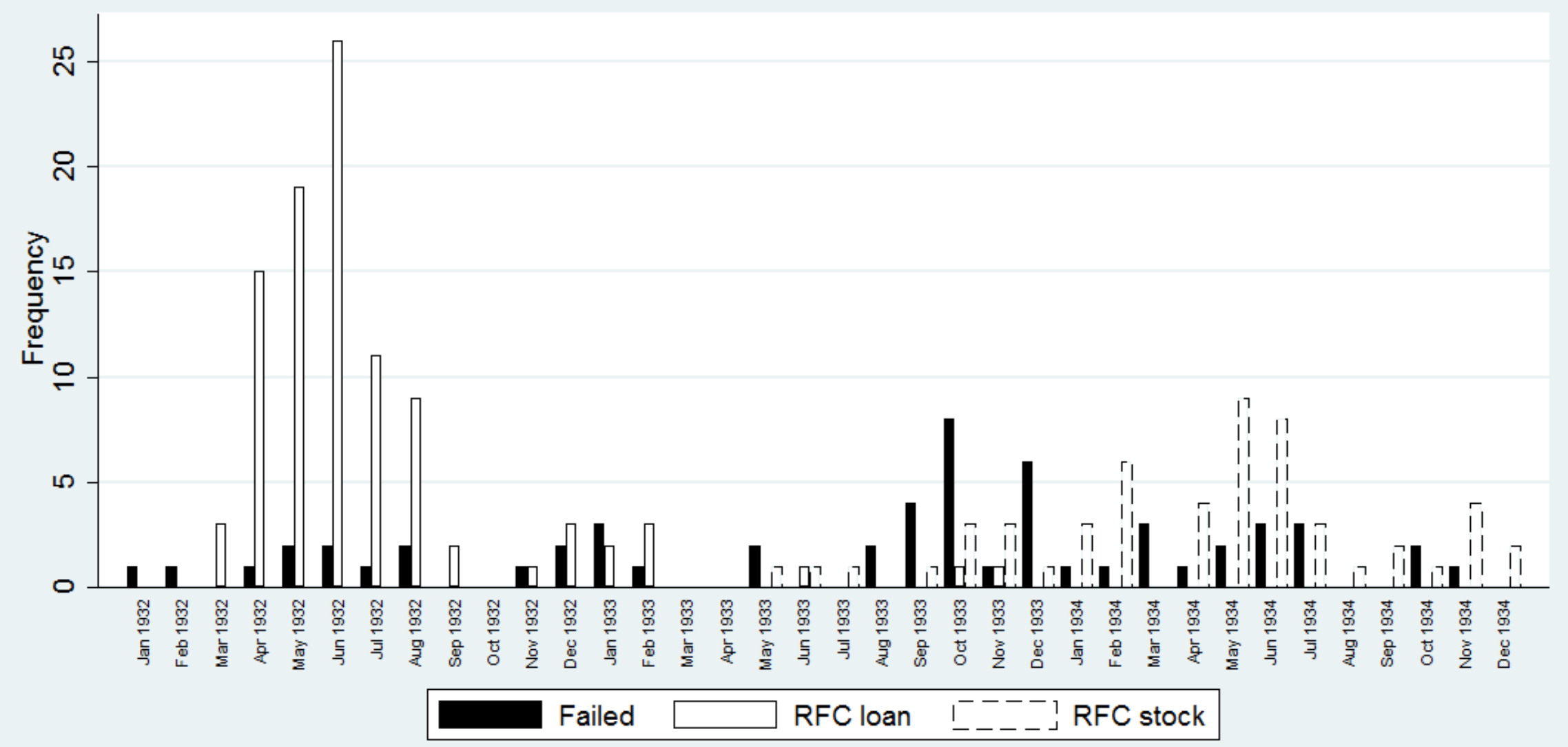


Figure 2: Histogram of Second Period (Post-March 1933) Residuals

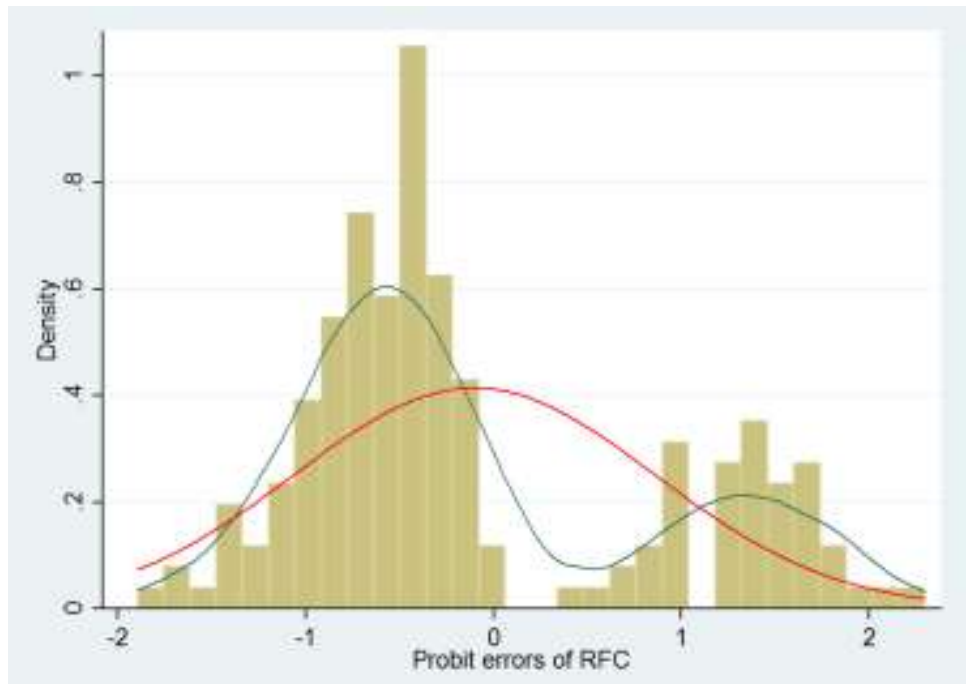

(a) Deviance residual of RFC assistance dummy (full model, probit)

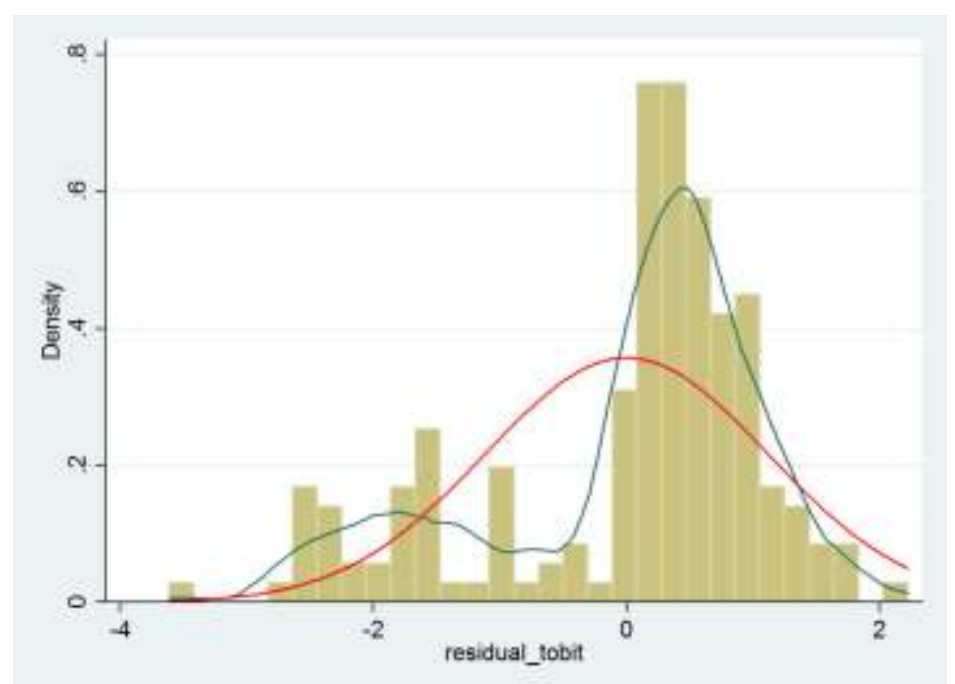

(b) Generalized residual of log of days to RFC assistance (full model, tobit)

Yellow bins are the histogram of the errors. Tan curve is the kernel fitted density function of the residuals: the probit residual is the deviance residual after probit; the tobit residuals are the generalized residuals derived according to Gourieroux et al (1987). The red curve is the normal density function. 